
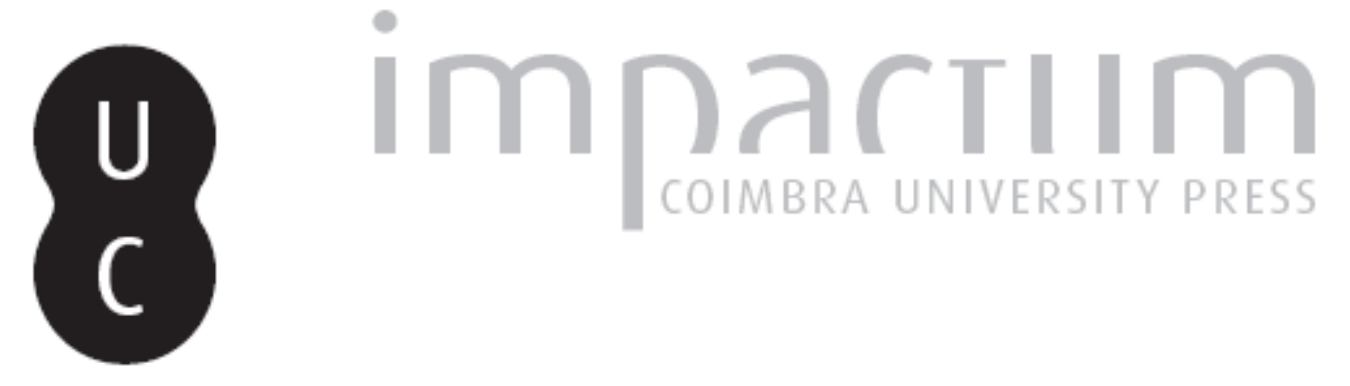

\title{
As origens do povoamento da região de Viseu
}

Autor(es): $\quad$ Alarcão, Jorge de

Publicado por: Imprensa da Universidade de Coimbra

URL persistente:

URI:http://hdl.handle.net/10316.2/45440

DOI:

DOI:https://dx.doi.org/10.14195/1647-8657_35_1

Accessed : $\quad$ 26-Apr-2023 14:19:02

A navegação consulta e descarregamento dos títulos inseridos nas Bibliotecas Digitais UC Digitalis, UC Pombalina e UC Impactum, pressupõem a aceitação plena e sem reservas dos Termos e Condições de Uso destas Bibliotecas Digitais, disponíveis em https://digitalis.uc.pt/pt-pt/termos.

Conforme exposto nos referidos Termos e Condições de Uso, o descarregamento de títulos de acesso restrito requer uma licença válida de autorização devendo o utilizador aceder ao(s) documento(s) a partir de um endereço de IP da instituição detentora da supramencionada licença.

Ao utilizador é apenas permitido o descarregamento para uso pessoal, pelo que o emprego do(s) título(s) descarregado(s) para outro fim, designadamente comercial, carece de autorização do respetivo autor ou editor da obra.

Na medida em que todas as obras da UC Digitalis se encontram protegidas pelo Código do Direito de Autor e Direitos Conexos e demais legislação aplicável, toda a cópia, parcial ou total, deste documento, nos casos em que é legalmente admitida, deverá conter ou fazer-se acompanhar por este aviso.

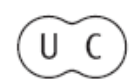


UNIVERSIDADE DE COIMBRA

FACULDADE DE LETRAS

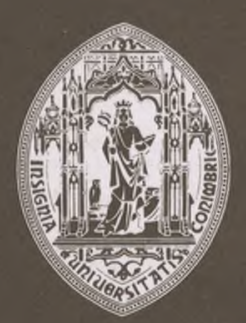

\section{CONIMBRIGA}

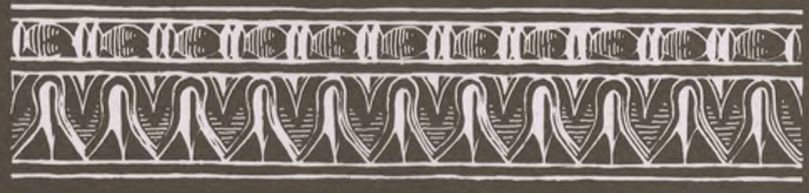

VOLUME XXXV - 1996 
JoRGE DE ALARCÃo

Professor da Faculdade de Letras de Coimbra

\section{AS ORIGENS DO POVOAMENTO DA REGIÃO DE VISEU}

"Conimbriga" XXXV (1996) p. 5-35

RESUMO: O autor apresenta uma hipótese de agrupamento dos castros da Idade

do Ferro na região de Viseu e faz corresponder, a cada grupo, uma unidade étnica, que as fontes epigráficas romanas permitem nomear. Mostra que, na época romana, não há aldeias, mas um povoamento disperso por villae e casais. A aldeia parece ser, na região, uma criação medieval. Apresentam-se mapas das aldeias citadas na documentação até ao séc. XII e põe-se o problema da origem desses pequenos aglomerados populacionais.

ABSTRACT: The author lances the hypothesis that the Iron Age castra in the Viseu area (northern part of central Portugal) were geographically grouped together. He further postulates that each group represents an ethnic entity whose name may be retrieved from Roman sources. Villages as such did not exist during the Roman period; the population being dispersed amongst hamlets and villae. It seems that villages only came into being in Medieval times. Those documented up to the twelfth century are shown on the maps presented, while the problem of their origin is raised.

Conimbriga, 35 (1996) 5-35 
(Página deixada propositadamente em branco) 


\section{AS ORIGENS DO POVOAMENTO DA REGIÃO DE VISEU *}

A área que aqui analisamos é a da civitas romana de Viseu. A sua delimitação é fácil a Ocidente, pelas serras do Caramulo (na Idade Média, de Alcoba) e de Arada (na época medieval, de Fuste); a Norte, pela serra de Montemuro; a Nordeste, pelas serras de Leomil e da Lapa; a Sudeste, pela serra da Estrela. A Sul, a civitas de Viseu confinava com a de Bobadela (Oliveira do Hospital). É difícil traçar esta fronteira meridional, que seria artificial, porque nenhum acidente geográfico, monte ou rio, separava as duas civitates. Nem sequer estrada, que às vezes servia de raia. Incluímos, na nossa análise, o antigo território medieval de Senhorim, onde Nelas é hoje o aglomerado urbano mais importante, e bem assim a parte norte do concelho de Tondela. Os castros de S. Romão (Seia) e Guardão (na serra do Caramulo) poderiam ser pontos nos confins das duas civitates, cuja fronteira talvez se não afastasse muito de uma linha recta entre os dois sítios.

A área foi, nos últimos anos, objecto de vários estudos; por ordem cronológica, citaremos os nossos próprios, A cidade romana de Viseu (ALARCÃO, 1989) e Geografia política e religiosa da civitas de Viseu (ALARCÃO, 1989 a); depois, mais importante, a tese de doutoramento de João L. Inês Vaz, A civitas de Viseu (Espaço e sociedade) (VAZ, 1993); por último, a tese de mestrado de Ivone Pedro, $O$ povoamento proto-histórico na região de Viseu (PEDRO, 1995).

Estas duas teses, sem as quais este nosso artigo teria sido impossível, não foram ainda publicadas. Para elas remetemos o leitor

* Agradecemos ao Dr. João da Cunha Matos, à Doutora Leontina Ventura e ao Doutor João Inès $\mathrm{Vaz}$ as preciosas observações que nos permitiram corrigir ou melhorar, nalguns pontos, o original deste artigo. 
que queira inteirar-se de pormenores, designadamente bibliográficos, sobre as estações da Idade do Ferro e romanas a que aqui aludimos e que nos nossos mapas cartografamos. O nosso trabalho é a reinterpretação dos dados apresentados por João L. Inès Vaz e Ivone Pedro, mas não dispensa a leitura das duas teses citadas, cuja publicação desejamos. Acrescentamos aos dois trabalhos referidos um estudo sobre o povoamento medieval, tendo em vista a identificação de sobrevivências ou contrastes. Também o nosso estudo não dispensa a consulta de valiosas monografias locais sobre Viseu (ARAG̃̃O, 1894), Algodres (MARQUES, 1938), Seia (BIGOTTE, 1981), Nelas (LOUREIRO, 1957), Mangualde (SILVA, 1978) e Castro Daire (CORREIA, ALVES e VAZ, 1986). A documentação medieval utilizada foi a dos DMP (DR e DP), do Livro Preto dA SÉ DE CoImbra e do Livro SANTO DE SANTA CRUZ. Admitimos que as localidades cartografadas por Merêa e Girão (1943) estão realmente citadas na documentação publicada em PMH (DC), e não procedemos à verificação.

$\mathrm{O}$ nosso artigo é um mero ensaio que apela a mais aprofundado e rigoroso estudo por parte dos investigadores que trabalham sobre esta região.

\section{O Povoamento na Idade do Ferro e no Período Romano}

$\mathrm{Na}$ região de Viseu, na Idade do Ferro, não parece ter havido povoamento disperso por casais; a população concentrava-se em castros, em posições naturalmente defendidas.

A carta 1 representa, com uma estrela, os castros da região, castros cuja lista, elaborada por Ivone Pedro na sua dissertação de mestrado, a seguir apresentamos. Para facilitar uma eventual consulta ao trabalho de Ivone Pedro, que descreve os castros e regista a respectiva bibliografia, apresentamos a seguir ao nosso número de ordem e entre parênteses, os números que os castros têm no trabalho desta autora. Ao nome do castro seguem-se os da freguesia e do concelho.

1. (20). Paços de Vilharigues, Vilharigues, Vouzela

2. (19). Senhora do Castelo, Vouzela, Vouzela

3. (14). Banho, Serrazes, S. Pedro do Sul

4. (13). Nossa Senhora da Guia, Baiões, S. Pedro do Sul

5. (12). Senhora da Boa Morte, S. Cristóvão de Lafões, S.

Pedro do Sul

Conimbriga, 35 (1996) 5-35 
6. (10). Cárcoda, Carvalhais, S. Pedro do Sul

7. (11). Pinho, Pinho, S. Pedro do Sul

8. (9). Ucha, Sul, S. Pedro do Sul

9. (8). S. Martinho das Moitas, S. Martinho das Moitas, S. Pedro do Sul

10. (7). S. Macário, Sul, S. Pedro do Sul

11. (2). Cabril, Cabril, Castro Daire

12. (D- Portas de Montemuro, Ester, Castro Daire

13. (3). Castro Daire, Castro Daire, Castro Daire

14. (4). Outeiro da Maga, Moledo, Castro Daire

15. (5). S. Lourenço, Moledo, Castro Daire

16. (6). Vila Cova-à-Coelheira, Vila Cova-à-Coelheira, Vila Nova de Paiva

17. (15). Santa Bárbara, Ferreira de Aves, Sátão

18. (16). Santos Idos, Sátão, Sátão

19. (17). Senhora do Barrocal, Romãs, Sátão

20. Castelo dos Mouros, Penaverde, Aguiar da Beira

21. (18). Rio de Moinhos, Rio de Moinhos, Sátão

22. (30). Esmolfe, Esmolfe, Penalva do Castelo

23. (36). Senhora do Bom Sucesso, Chãs de Tavares, Mangualde

24. (37). Senhora do Castelo, Mangualde, Mangualde

25. (38). Cerca, Espinho, Mangualde

26. (22). Santa Luzia, Abraveses/Campo, Viseu

27. (23). Senhora do Crasto, Órgens, Viseu

28. (25). Aral, Vila Chã de Sá, Viseu

29. (24). Cruz, S. Cipriano, Viseu

30. (26). Castelo dos Mouros, Vila Chã de Sá, Viseu

31. (27). Castaínça, Fail, Viseu

32. (28). Três Rios, Parada de Gonta/Faíl, Tondela/Viseu

33. (29). Cocão, Silgueiros, Viseu

34. (34). Nossa Senhora do Crasto, Lobão da Beira, Tondela

35. (35). Ferreiros do Dão, Ferreiros do Dão, Tondela

36. (33). Nandufe, Nandufe, Tondela

37. (32). Guardão, Guardão, Tondela

38. (31). Outeiro Murado, Caparrosa, Tondela

39. (21). Campia, Campia, Vouzela

40. S. Romão, S. Romão, Seia

41. Cabeço de Castro, Torrozelo, Seia 
42.

$$
\text { Monte Negrume, Mangualde da }
$$

Serra, Gouveia

43. Gouveia, Gouveia, Gouveia

44. Folgosinho, Folgosinho, Gouveia

45. Castelo, Arcozelo, Gouveia

A existência do castro $n .^{\circ} 21$ é duvidosa: o sítio é apropriado a um povoado da Idade do Ferro mas não são visíveis muralhas e a cerâmica que à superfície se recolhe é incaracterística.

$\mathrm{O}$ castro $\mathrm{n}^{\circ}$ 20, identificado por João Vaz, não é tido em consideração por Ivone Pedro.

Os castros n.os 4, 22, 28, 29, 31 e 33, ocupados no Bronze final, parecem ter sido abandonados na Idade do Ferro.

Quanto ao castro n. ${ }^{\circ} 36$, seguramente ocupado nos séculos I e II d. C. , a sua origem pré-romana não está ainda provada.

À volta dos castros seguramente ocupados na Idade do Ferro (e também dos castros nos 20 e 36, embora estes, como acabámos de ver, possam suscitar dúvidas) traçámos os territórios que poderiam alcançar-se em 60 minutos de marcha a partir do povoado. A análise dos territórios de exploração dos castros inclina-nos a supor que uns tinham territórios de 60 minutos e outros, apenas de 30 minutos. Com efeito, se os territórios de 30 minutos nunca coincidem, os de uma hora às vezes sobrepõem-se. A existência de castros com territórios de meia hora e de outros com territórios de 60 minutos não deve surpreender. Com efeito, os povoados não têm todos a mesma extensão. Esta oscila entre $<2 \mathrm{e}>5$ hectares. Não se verifica o caso de um eventual território de 60 minutos de um castro grande se sobrepor ao território de 30 minutos de um castro pequeno. Por outras palavras: admitindo que os castros maiores tinham territórios de 60 minutos e os menores, de 30, os territórios não se sobrepõem.

Observa-se uma situação anómala: três castros (n.os 30, 31 e 32) estão tão próximos uns dos outros que os seus territórios (se os tivéssemos traçado) seriam quase coincidentes. Parece-nos dificilmente admissível a sua contemporaneidade. O castro de Três Rios (n. ${ }^{\circ} 32$ ) foi apenas objecto de uma curta intervenção e os materiais recolhidos são datáveis, por moedas, dos séculos III e IV d. C. O Castelo dos Mouros (n. ${ }^{\circ}$ 30) é, indiscutivelmente, um povoado da Idade do Ferro. O castro de Castaínça (n. ${ }^{\circ}$ 31) parece ter sido ocupado no Bronze Final e ainda na Idade do Ferro, mas nada permite assegurar a sua ocupação durante toda a Idade do Ferro. Assim, propomos uma ocupação sucessiva, por esta ordem: Castaínça, Castelo dos Mouros, castro dos Três Rios. Traçámos o território de 60 minutos à volta do Castelo dos Mouros. 
Do mapa 1 depreende-se que não havia, no território de Viseu, e na Idade do Ferro, nenhum fenomeno de sobrepovoamento que tornasse a terra escassa e que conduzisse a conflitos.

O castro de Santa Luzia ( . $^{\circ} 26$ ), bem no centro do territorio, serviu talvez de lugar central. Aparentemente, coexistiu com o da Senhora do Crasto (n. ${ }^{\circ}$ 27), onde também se recolhe, à superfície, cerâmica do Bronze Final e da Idade do Ferro; mas só mais extensas escavações em Santa Luzia, e trabalhos na Senhora do Crasto, onde nunca se efectuaram escavações, poderá esclarecer se os dois povoados foram contemporâneos ou se o segundo não foi, a certa altura, abandonado. A contemporaneidade parece-nos difícil de admitir e por isso não traçámos o território em tomo da Senhora do Crasto.

Se Santa Luzia desempenhou funções de capitalidade, compreende-se melhor a instalação, nas suas imediações, do acampamento romano da Cava de Viriato. O castro não reuniria, porém, condições adequadas à instalação de uma cidade capital. Essa cidade, Viseu, foi fundada pelos Romanos apenas a quatro quilómetros, a sudeste.

No território, para a época romana, João Vaz identificou um certo número de villae e outros lugares a que deu o nome de habitat.

A villa era a grande unidade de exploração agrária, propriedade de um senhor, dominus, que a cultivava por meio de trabalhadores, fossem eles escravos ou livres assalariados. Não há, em todo o território de Viseu, inscrição romana que recorde escravo e só uma lembra um liberto. Daí não se pode inferir que os escravos não existiam: pobres, desconsiderados, podiam ser (e eram-no certamente) enterrados sem que ninguém lhes mandasse lavrar epitáfio. Mas, se pode ter havido escravos ( e houve-os certamente), não é menos possível a existência de assalariados livres.

A villa romana da Beira central não teria as dimensões da villa alentejana. Se, a sul do Tejo, as villae de 200 hectares eram frequentes (e não seriam raras, pelo menos no Baixo Império, as villae maiores), na Beira, um fundus de 50 hectares seria já uma grande propriedade, que garantiria talvez a quem a possuísse o ingresso na ordo decurionum, isto é, no senado municipal. João Vaz identificou 63 villae no território da civitas romana de Viseu. Parece um número um pouco elevado para o senado de uma modesta cidade como seria Viseu. Mas seriam decuriões todos os proprietários de villael E serão efectivamente villae todas as estações que João Vaz classifica como tais? 
O que João Vaz classifica de habitat é uma estação romana de pequena dimensão e onde não são visíveis, à superfície, senão telhas e fragmentos de cerâmica comum. Não se observam, nessas estações, nem pedras aparelhadas que revelem construções cuidadas, nem elementos de colunas, nem terra sigillata ou outras cerâmicas denunciadoras de um nível de vida elevado, que seria o de uma villa. Não cremos que o habitat de João Vaz corresponda verdadeiramente a uma aldeia, mas apenas a um casal isolado.

A aldeia parece ter existido, na época romana, na região de Trás-os-Montes. É o que se deduz dos trabalhos de Sande Lemos (1993) e de Paulo Amaral (1993), trabalhos apresentados, respectivamente, como dissertação de doutoramento e tese de mestrado e infelizmente ainda não publicados. A aldeia romana, como parece dever depreender-se dos trabalhos citados, é uma realidade que se pode identificar hoje por uma área de dispersão de achados da ordem dos 3 a 4 hectares. Ora, isto não existe na área central do território viseense. O habitat de João Vaz é qualquer coisa que corresponde apenas a centenas de metros quadrados (comunicação pessoal).

Aldeias, não as haveria no território em torno de Viseu; só na periferia: eram os castros.

Temos dificuldade em agrupar os castros na parte noroeste e norte do território. Somos tentados a reunir num grupo os n.os 1 a 8 (excluímos o de Nossa Senhora da Guia, n. ${ }^{\circ} 4$, por termos muitas dúvidas sobre a sua ocupação na Idade do Ferro) e noutro, os n. ${ }^{\circ} 9$ a 17 . O primeiro grupo corresponde a uma unidade geográfica bem definida, a região de Lafões, que compreende os concelhos de S. Pedro do Sul, Vouzela, Oliveira de Frades, e as freguesias de Alva e Mamouros (do concelho de Castro Daire) e de Ribafeita, Bodiosa, Campo, Lordosa e Calde (do concelho de Viseu) (GlRÃO, 1933: 86). O segundo grupo corresponde à área do Alto Paiva, também ela, uma zona com características geográficas próprias.

Num dos castros da região de Lafões, o de Pinho (n. ${ }^{\circ} 7$ ), encontrou-se uma ara à divindade indígena Banda Alabaraicus Sulensis (VAZ, 1993: 251). Os epítetos da divindade são, possivelmente, derivados de etnónimos. A ara seria, pois, dedicada ao deus Banda dos Alabari dos Sulenses. Alabari seria uma unidade étnica menor, integrada numa unidade étnica maior, a dos Sulenses. O hidrónimo Sul, que designa um afluente do Vouga, e os topónimos Sul (sede de freguesia) e S. Pedro do Sul (sede de concelho) recordariam o etnonimo pré-romano. O nome romano das Teimas de S. Pedro do Sul poderá ter sido Aquae Sulis. 
Poderá o etnonimo Alabari ser derivado de uma raiz Alãbal Alãba teria dado Alva, que subsiste na área, como topónimo, em Alva e Figueiredo de Alva.

Se este grupo de castros tinha um lugar dominante, esse poderia ser o castro da Cárcoda (n. ${ }^{\circ}$ 6), de todos o maior; mas é certo que nem sempre o lugar dominante é o mais vasto.

Os nomes destes castros são-nos desconhecidos, com uma excepção: a ara ao Banda Ocel(aicus) ou Ocel(ensis) do castro da Ucha (n. ${ }^{\circ}$ ) (VAZ, 1993: 254) permite restituir um topónimo Ocelum, que seria o do castro (Contra, vid. BRAÑAS, 1995: 245). No mesmo povoado, uma ara a Marte foi consagrada pelos Depenori (VAZ, 1993: 228), que podemos talvez considerar como uma das linhagens ou clãs residentes no castro. Assim, teríamos, integradas na unidade étnica maior dos Sulenses, duas unidades étnicas menores, as dos Alabari e a dos Depenori.

$\mathrm{Na}$ época romana, todos os castros desta região de Lafões foram mantidos. Surgiram dois aglomerados novos: no lugar da Várzea, as águas sulfurosas foram aproveitadas e em tomo das termas surgiu possivelmente um vicus, cujo nome poderá ter sido Aquae Sulis, como acima dissemos; por outro lado, os achados do Carvalhal do Estanho (n. ${ }^{\circ}$ 245 do inventário elaborado por VAZ, 1993) fazem suspeitar de uma aldeia, talvez em relação com as minas de estanho de Bejanca (n. ${ }^{\circ} 246$ de VAZ, 1993). Mas não foi na época romana que surgiu o povoamento disperso intercalar de frequentes casais e pequenas quintas numa apertada malha de aldeias, que hoje caracteriza a região. Com efeito, na época romana, João Vaz só identificou cinco lugares que classificou de habitat (n. ${ }^{\text {s }} 107,160,204,241$ e 242) e duas villae (n. ${ }^{\text {ss }} 240$ e 243).

A região do Alto Paiva compreende nove castros, mais dois que a anterior. Poderá discutir-se, em primeiro lugar, se os castros de S. Macário (n. ${ }^{\circ}$ 10) e de S. Martinho das Moitas (n. $\left.{ }^{\circ} 9\right)$ devem integrar-se neste grupo ou no de Lafões. Geograficamente, não cabem na região bem demarcada de Lafões. Administrativamente, no séc. XI, a área destes castros também não estava integrada no território de Lafões, mas no de Penafiel de Covas (MERÊA E GIRÃO, 1943). Poderá também discutir-se a integração do castro de Santa Bárbara (n. $\left.{ }^{\circ} 17\right)$ neste grupo do Alto Paiva.

Se os castros da região de Lafões eram ocupados por uma etnia designada pelo nome de Sulenses, os castros do Alto Paiva seriam habitados pelos Magari. Com efeito, em Lamas de Moledo, que fica perto do Outeiro da Maga ( . $\left.^{\circ} 14\right)$, encontrou-se uma famosa inscrição 
rupestre em língua lusitana que recorda um sacrifício feito pelos Veiaminicori aos deuses Crongea Magareaicus, Petranius e Júpiter Caielobrigensis (CURADO, 1989: 352). Os Veiaminicori seriam uma unidade étnica menor, possivelmente residente no Outeiro da Maga. Mas o epíteto Magareaicus de Crougea permite deduzir a existência de outra unidade étnica, que supomos maior: a dos Magari. Ou deverá Magareaicus relacionar-se com o substantivo bretão mager, que significa "aquele que nutre"? Preferimos relacionar o epíteto com um etnonimo Magari, que parece conservado no nome do castro de S. Macário (n..$\left.^{\circ} 10\right)$ e, talvez ainda, no nome de Outeiro da Maga.

A inscrição de Lamas de Moledo revela-nos ainda o nome de um castro, Caielobriga, no qual se adorava Júpiter. Onde ficaria Caielobriga, não sabemos dizê-lo. Mas não é impossível que o Outeiro da Maga (n. ${ }^{\circ}$ 14) fosse Caielobriga. Aqui viveriam os Veiaminicori, como em Ocelum viviam os Depenori: o nome do castro podia ser muito diferente do(s) $\mathrm{da}(\mathrm{s})$ linhagen(s) nele residente(s). A reforçar esta hipótese, na área do castro existe o topónimo Cela, que tem a mesma raiz de Caielobriga (VAZ, 1993: 238).

Tal como na área de Lafões, também na do Alto Paiva não houve, na época romana, grandes transformações. Com excepção do castro das Portas de Montemuro (n. ${ }^{\circ} 12$ ), todos os outros apresentam vestígios de romanização; e nem sequer do primeiro podemos dizer com segurança que foi abandonado. Junto do castro do Outeiro da Maga (n. $\left.{ }^{\circ} 14\right)$, em Lamas de Moledo, parece ter-se instalado um vicus. Os casais não são frequentes e as possíveis villae são raras.

A zona de Ferreira de Aves, onde se não conhece senão o castro de Santa Bárbara (n. ${ }^{\circ}$ 17), foi agora ocupada por uma ou duas villae e cinco (ou seis) casais.

Um terceiro grupo de castros, também correspondente a uma região geográfica individualizada, a do Alto Dão, compreende os n. ${ }^{\text {os }} 18$ a 25 .

A epigrafia da área (veja-se estudo actualizado em VAZ, 1993) revela os nomes de quatro unidades étnicas menores: os Oilieni, os Tatibi, os Nili e os Caieli. Deriva-se o nome dos primeiros, de uma ara consagrada Bandi Oilienaico, encontrada em Fundo de Vila, Esmolfe, Penalva do Castelo; o dos segundos, de uma inscrição dedicada Bandi Tatibeaico, recolhida em Queiriz, Fomos de Algodres; o dos Nili, de uma ara onde se lê Crougae Nilaicui, hoje na igreja da Freixiosa, Mangualde; e o dos Caieli, de uma inscrição consagrada Colovesei Caieioni Cosigos, actualmente na capela de S. Clemente, Furtado, Fomos de Algodres. 
Talvez esta última revele uma unidade étnica menor, os Caieli (recorde-se o topónimo Caielobriga no Alto Paiva) e uma unidade étnica maior, a dos Cosigos ou Cosigosenses. Podemos talvez, pensando que as inscrições não viajaram muito, atribuir os Oilieni ao castro de Esmolfe (n. ${ }^{\circ} 22$; terá sido este castro efectivamente abandonado na Idade do Ferro, como pretende Ivone Pedro?), os Tatibi ao Castelo dos Mouros (n. ${ }^{\circ}$ 20), os Nili ao castro da Senhora do Castelo (n. $\left.{ }^{\circ} 24\right)$ e os Caieli ao da Senhora do Bom Sucesso (n. $\left.{ }^{\circ} 23\right)$.

Todos os castros deste grupo, com excepção dos da Senhora do Barrocal (n. ${ }^{\circ}$ 19) e Esmolfe (n. ${ }^{\circ}$ 22), apresentam vestígios evidentes de romanização. Alguns parecem ter ganho, na época romana, particular importância. Assim, o da Senhora do Castelo (n. ${ }^{\circ}$ 24), chamado Araocelum (ALARCÃO, 1989 a: 307). Situado num cruzamento de caminhos, servindo possivelmente de mutatio para quem vinha de Viseu e de mansio para quem vinha de Bobadela, tornou-se um nó viário. É possível que parte da população tenha descido para lugar mais baixo, onde poderá ter surgido um aglomerado precursor da actual cidade de Mangualde. Outro castro que parece ter sido importante na época romana é o da Senhora do Bom Sucesso (n. ${ }^{\circ}$ 23). Seria mansio para quem vinha de Viseu.

No castro da Senhora do Barrocal (n. $\left.{ }^{\circ} 19\right)$ não são visíveis, como dissemos, vestígios de romanização. Algures, nas imediações, deve ter havido uma mansio ou mutatio. Podemos mesmo imaginar que em torno dessa pousada ou estação de muda se criou um vicus, para o qual se teria transferido a população do castro. O certo, porém, é que nenhuma das estações romanas conhecidas na área parece poder interpretar-se como vicus, mansio ou mutatio.

Ao contrário das anteriores regiões de Lafões e do Alto Paiva, no Alto Dão observa-se, no período romano, uma considerável proliferação de casais e de villae, que começaram a definir a paisagem actual da região.

Entre o Alto e o Baixo Dão intercala-se uma zona que, na Idade do Ferro, não foi povoada. Na Idade Média era o território de Senhorim.

A área, na época romana, foi atravessada pela estrada que ligava Viseu à splendidissima civitas da Bobadela. O percurso segue-se sem dificuldade de Viseu a Alcafache. É difícil decidir se ia depois por Santar e Canas de Senhorim ou por Vilar Seco e Nelas. Seja como for, este caminho romano que seguro segue de Viseu a Alcafache devia ir entroncar na estrada de Bobadela a Mangualde. 
O povoamento romano é, nesta área, disperso. Temos de supor, na estrada, talvez entre Carvalhal Redondo e Canas de Senhorim, uma mutatio. Seria em Laja do Quarto? Ou, se a estrada ia por Vilar Seco e Nelas, em Moledo? A estação de muda, porém, podia ser só isso; não temos razão para supor um vicus. A área não tinha, pois, na época romana, nenhum aglomerado urbano.

$\mathrm{Na}$ área de Tondela incluímos os castros n.os 34 a 37. Talvez se devam reunir ao mesmo grupo os n.os 38 e 39. Não temos aqui epigrafia da qual se possa deduzir o nome da unidade étnica maior ou suspeitar dos etnónimos menores.

$\mathrm{Na}$ época romana, a população da área continuou a viver nos castros: são raros os casais e as villae. O panorama é de retraso, de marginalidade.

Para além do Mondego, e até às alturas da Serra da Estrela, o território entre a ribeira de Salgueirais (que aflui ao Mondego perto de Vila Boa do Mondego) e, a sul, o castro de S. Romão (Seia), constitui uma área que supomos integrada também na civitas romana de Viseu, embora nem João Vaz nem Ivone Pedro assim pensem.

O castro de S. Romão ( . $^{\circ} 40$ ), onde Senna-Martinez tem nos últimos anos realizado escavações, é bem conhecido desde os tempos de Martins Sarmento, que o deu a conhecer e lhe traçou a planta. O mesmo Martins Sarmento localizou outro castro na margem esquerda do rio Cobrai, a 500 metros a Norte de Torrozelo: o Cabeço de Castro (n. $\left.{ }^{\circ} 41\right)$.

Supomos que houve castros também em Gouveia (n. ${ }^{\circ}$ 43) e Folgosinho (n..$\left.^{\circ} 44\right)$ (ALARCÃO, 1993), embora a continuada ocupação dos lugares tenha por completo destruído os vestígios. No sítio do Castelo (n. ${ }^{\circ}$ 45), na confluência das ribeiras de Gouveia e de S. Paio, há outro pequeno castro. Mais incerto é o de Monte Negrume (n. $\left.{ }^{\circ} 42\right)$ (AlARCÃO, 1993).

$\mathrm{Na}$ época romana manteve-se, seguramente, o castro de S. Romão; mantiveram-se também, provavelmente, os de Gouveia e Folgosinho.

A área era atravessada por uma via que, vinda de S. Romão, ia por Paços da Serra (em cujas imediações se encontrou um miliàrio) até Gouveia; aqui encontrava a grande via de Mérida a Braga, que vinha, mais proximadamente, de Valhelhas e Famalicão (do lado oriental da Serra da Estrela) e ia depois cruzar o Mondego perto de Abrunhosa-a- Velha, com destino a Mangualde e Viseu.

Apesar das boas comunicações, a área não parece ter atraído grande povoamento na época romana; mas também é certo que não tem 
havido prospecções sistemáticas na zona entre a via e o Mondego, onde é legítimo esperar o achado de mais villae e casais.

\section{O POVOAMENTO MEDIEVAL}

\section{Na área em torno de Viseu}

$\mathrm{Na}$ época tardo-romana, Viseu foi amuralhada. A essas muralhas se referem os documentos medievais que falam do muro vedrò (ALARCÃO, 1989: 23). Não sabemos se Bobadela, a outra cidade romana da Beira central, também recebeu muralhas: delas não há vestígios. Por qualquer razão, porém, enquanto Bobadela decaía, Viseu tomava-se sede de bispado no período suévico, com nove paróquias dependentes, incluindo a da própria cidade e a de Caliábria, que depois se tomaria também sede episcopal.

A tentativa de Almeida Fernandes (1967: 53-55) de identificar as paróquias suévicas de Viseu não nos parece bem sucedida. Apenas concordamos com o autor quanto a Caliábria e a Suberbeno; e, quanto a esta última, não temos a certeza de que a sede tenha sido em Seia, se bem que a área da paróquia corresponda, com toda a probabilidade, ao território entre o Mondego e a Serra da Estrela, isto é, a uma daquelas subunidades que distinguimos no povoamento proto-histórico e romano da região de Viseu. Parece-nos difícil não admitir maior correspondência das paróquias suévicas com as subunidades proto-históricas e romanas.

O primeiro bispo nomeado da diocese viseense é Remisol, que assina as actas do segundo concílio de Braga, em 572. João L. Inês Vaz escavou recentemente a basílica paleocristã de Viseu, que fica situada perto da actual Sé.

A importância da cidade no período visigótico é testemunhada por uma emissão de moeda de Suintila (MATEU Y LLOPIS, 1936: 360-361).

Sobre o domínio muçulmano da região, é pouco o que conhecemos. Afonso I (739-757) reconquistou Viseu. Mas em 825 e 833, respectivamente, al-Abbas ibn Abd Allah al-Kurashi e al-Walid ibn Hisham partiram de Viseu para atacarem a Galiza, o que parece pressupor uma reocupação de Viseu pelos Muçulmanos (LÉVI-PROVENÇAL, 1950(1): 70, 204-205).

Afonso III (866-910), segundo reza a Crónica de Albelda, "povoou" a cidade, o que implica a sua reconquista. Ordonho, filho de 
Afonso III, em 901 reuniu tropas em Viseu para uma correria que fez além do Tejo e mesmo do Guadiana (LÉVI-ProvENÇAL, 1950(1): 385), ou apenas até à região da Lousa (vid. FERNANDES, 1990: 50, nota 47). E Ramiro II viveu em Viseu de 926 a 930 (SÁEZ, 1947).

Almançor, hachib do califa Hisham II, em 977 estacionou em Viseu antes de atacar a Galiza e aí se lhe reuniram vários condes cristãos da região, condes que reconheceram a sua suzerania. Viseu passou, pois, de novo, para a posse dos Muçulmanos (LÉVI-PROVENÇAL, 1950(11): 249).

Em algum tempo o território de Lafões deve ter passado de novo para o domínio cristão porque foi reocupado, em 1026, pelo cadi de Sevilha, Abu Alcámine Mohâmede (AZEVEDO, 1939: 121).

Afonso V, em 1028, pôs cerco a Viseu mas morreu de uma ferida que então the foi feita por um archeiro muçulmano (AZEVEDO, 1939: 122). Seria Fernando Magno quem, em 1057 ou 1058, reconquistaria a cidade, juntamente com Seia (AZEVEDO, 1940: 3). Teria sido então reconquistado também o território de Lafões?

Talvez na posterior reorganização do território tenham colaborado Garcia Rodrigues e seu irmão Paio, que filharam aos Mouros a região de Leomil (Moimenta da Beira), região que o conde D. Henrique depois lhes doou (DMP, DR 1(2): 515-516). De qualquer forma, Garcia Rodrigues era um magnate da região porque confirma documentos de D. Henrique e D. Teresa datados de 1110 a 1128.

D. Teresa, segundo Almeida Fernandes, terá tido corte em Viseu e aqui terá nascido, em 1109, D. Afonso Henriques (FERNANDES, 1991: 227).

Em 1123, Viseu recebeu carta de foral.

Num círculo de 10 quilómetros, isto é, de cerca de duas horas de caminho a pé, em torno de Viseu, não observamos, na época romana, senão villae e casais: a aldeia, como vimos, não existia. Ora, no séc. XII, as aldeias são numerosas. Mais numerosas ainda do que a nossa carta 2 sugere: com efeito, a inquirição mandada fazer por D. Teresa em 1127 (DPM, DR 1(1), n. ${ }^{\circ}$ 74) revela nomes que não sabemos identificar por não figurarem na carta 1:25. 000. Só estudos de microtoponímia, feitos a partir dos livros de registo das matrizes prediais, poderão, eventualmente, conduzir à identificação desses lugares registados no documento de $\mathrm{D}$. Teresa e ignotos.

E reduzido o número de aldeias num raio de 5 quilómetros/ 1 hora de marcha. Isso não surpreende: as terras desse primeiro círculo seriam, na sua maior parte, cultivadas por moradores da cidade que, diária ou 
regularmente, se deslocariam aos campos. Se alguma surpresa nos causa a carta, é antes a presença de tantas aldeias nesse círculo, a ocidente.

O maior número de aldeias concentra-se no círculo de 1 a 2 horas de marcha; mas aqui surpreende que a distribuição se não faça ao longo das vias, mas se concentre também a ocidente da cidade.

Talvez a particular natureza dos granitos dessa área permitisse solos mais espessos e rendimentos mais elevados; talvez os vales dos rios tivessem mais amplos alvéolos onde se alojassem as aldeias. $\mathrm{Na}$ ausência das cartas geológica e de capacidade dos solos não podemos entender devidamente essa opção pelo quadrante ocidental.

As distâncias a que as aldeias identificadas a ocidente de Viseu se encontram umas das outras não permite admitir, para muitas delas, termos superiores a 80 hectares, isto é, muito pequenos. Hoje, no Barroso, um termo de $1350 \mathrm{~m}$. de raio, isto é, de 572 hectares, é normal (LEMA, 1978: 80). Em 1572, o termo de Vilaça (Montalegre) não ultrapassava um raio de $1400 \mathrm{~m}$. (FREUND, 1874), quer dizer, uma área global de 625 hectares. Termos desta ordem são admissíveis para algumas aldeias viseenses mais afastadas umas das outras.

Algumas das aldeias seriam simples lugarejos de meia dozena de casas. Mas noutras, a inquirição de 1127 revela 14 ou até 16 prédios \{casales), o que nos permite restituir 70 ou 80 habitantes (assumindo que cada fogo teria cinco membros). Talvez houvesse mesmo aldeias maiores. A inquirição de D. Teresa só regista os prédios foreiros da "coroa". Ora, as aldeias poderiam ter prédios foreiros de outros senhorios; e, no séc. XI, por toda a Europa havia pequenos proprietários livres (DUBY, 1971: 240; GARCIA DE CORTÁZAR, 1983: 19). A documentação de D. Sancho I (Azevedo, Costa e Pereira, 1979) deixa, porém, supor que, para a generalidade do país, uma aldeia de 16 famílias era já grande: com efeito, é esse o limite máximo dos povoados nas cartas de aforamento colectivo concedidas pelo rei, cartas que revelam de 3 a 16 povoadores (com suas famílias). Na região de Mâcon (França), também nos séculos XI e XII, as aldeias raramente ultrapassavam a vintena de casais (DUBY, 1971: 42).

Se parece difícil calcular a dimensão das aldeias, a das propriedades parece também indeterminável com os dados fornecidos pela documentação do séc. XII. Aliás, aqui, como no resto da Europa, "a dimensão dos prédios [era] extremamente variável e não se pode pretender calcular a superfície média deles“ (DUBY, 1971: 39). A maior parte dos documentos fala de hereditates e na inquirição de 1127 citam-se sobretudo casais. Estes termos não têm sentido preciso. Sobretudo, 


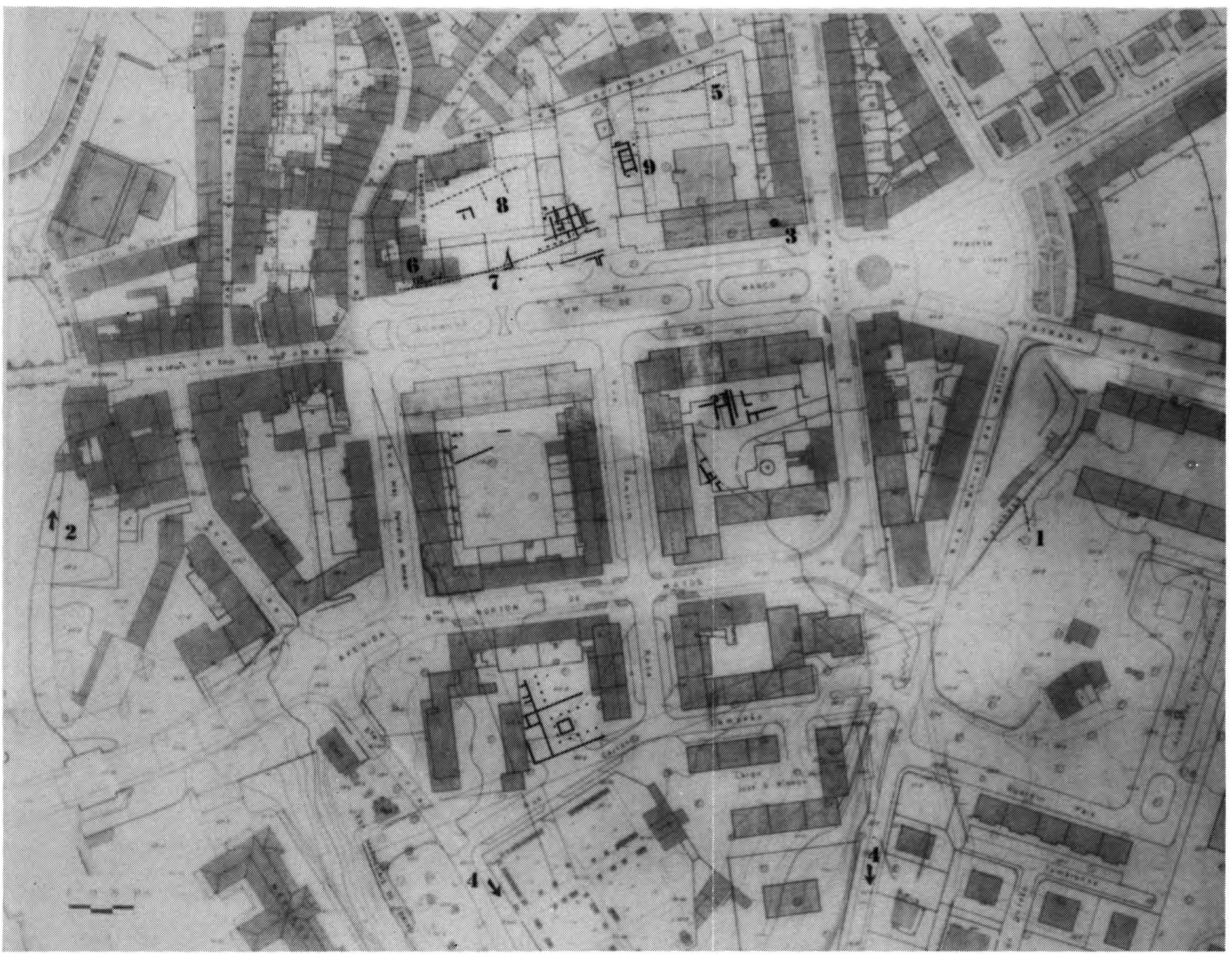

FIG. 1 - Planta aerofotogramétrica de Tomar, Esc. 1/25. 000: n. ${ }^{\circ} 1$ - vestígios de conduta subterrânea nas imediações da Associação Filarmónica de Gualdim Pais; n. ${ }^{\circ} 2$ - vala existente entre o estádio de futebol e a ponte das Ferrarias; $n .^{\circ} 3$ - mina de água; $n^{\circ} 4$ - vestígios de conduta subterrânea nas imediações da nascente de Marmelais; $n .^{\circ} 5$ - vestígios arqueológicos de conduta subterrânea; $n .^{\circ} 6$ - vestígios de colector em alvenaria; n." 7 e 8 - esgotos provenientes da ínsula da Alameda; n. ${ }^{\circ} 9$ - reservatório de água. 
não é possível equacionar o casal com a pequena propriedade e a hereditate com a grande. A hereditate pode ser um grande prédio rústico, como em DMP, DP IV, n. ${ }^{\text {os }} 292$ e 294; mas uma simples vinha, parua uinea, é chamada ereditate em DMP, DP 111, n. ${ }^{\circ} 499$. Por outro lado, Cipriano Fafilaz e sua mulher Maria vendem a João Gondesendes, em 1114, uma hereditate nostra propria que é constituída por prédios em diversas aldeias: Covas do Rio, Covas do Monte, Deilão, Posmil, e Gafanhão (DPM, DP III, n. ${ }^{\circ} 487$ ). Aqui, hereditate nostra propria equivale a "os nossos bens fundiários".

Também se não pode dizer que hereditate designa o(s) prédio(s) recebido(s) de herança, porque Pedro e sua mulher Gontinha, Atanagildo e sua mulher Bradi vendem em 1119 uma hérédité (sic) que habuimus de nostra apresuria e tudo quanto ibi habuimus et arumpemus (DMP, DP IV, n. $\left.{ }^{\circ} 81\right)$.

A incerteza quanto à dimensão das aldeias e das propriedades não obsta a uma conclusão: num raio de 2 quilómetros em torno de Viseu, na época romana só se encontram villae (no sentido de grandes propriedades) e casais dispersos; mas no séc. XII há aldeias.

A aldeia tem, na documentação medieval da região, o nome de villa. Não há, portanto, identidade entre a villa medieval e a villa romana, que corresponde a uma realidade diferente. As hereditates, os casales, as vineas e os pumares que no séc. XII se vendem, se escambam ou se doam, são ditos in villa (e segue-se o nome da villa), o que nos parece significar "no termo da aldeia de". É aliás também este o sentido de villa na França dos séculos XI e XII (DUBY, 1971: 41).

A emergência das aldeias no territorio viseense é um fenómeno que não podemos datar com precisão: tudo quanto podemos dizer é que eram numerosas no primeiro quartel do séc. XII. O seu aparecimento obriga-nos a pôr o problema da sua origem.

Numa primeira hipótese, a aldeia terá nascido de uma villa romana. O dominus, mantendo sob exploração directa parte do fundus, isto é, aquilo que se designa por reserva, terá distribuído, aos membros da subfamilia rustica, prédios (casais) talhados no antigo fundus. Mas as familias agora na posse dos casais, em lugar de se instalarem nas suas courelas, ter-se-ão mantido junto do paço senhorial.

Neste caso, não só deveríamos encontrar nas aldeias substanciais vestígios romanos, como o nome destas deveria ser um topónimo derivado de gentilicio romano e terminado em -lhã, -nhã ou -ã; -ana, ã ou -ão; -elhe; -igo, -im ou ino; -onha, -onho ou -onhe. Segundo alguns 
autores, topónimos como Paço, Paço ou Palácio designariam também as aldeias assim surgidas em tomo das villae tardo-romanas.

Ora, em primeiro lugar, nenhuma das aldeias citadas nos documentos do séc. XII tem nome assim terminado. Exceptuam-se Queirã e Ferronhe, que todavia não podem derivar-se de gentilicios romanos. Por outro lado, na documentação do séc. XII só encontramos uma aldeia chamada Palácios e outra Vila Palácio (referimo-nos ao aro de 15 quilómetros em tomo de Viseu). Para além disso, das aldeias citadas no séc. XII, só Fragosela e Canelas têm vestígios de villa romana. Assim, à primeira vista, não parece que as aldeias do séc. XII tenham, na generalidade, surgido de villae romanas.

Não excluímos, porém, em absoluto, a possibilidade de uma tal origem porque, para além de Fragosela e Canelas, cinco outras villae do concelho de Viseu parecem ter dado origem a aldeias, embora ainda não citadas na documentação do séc. XII: Cumieira, Lageosa, Pindelo de Silgueiros, Vila Meã, Guimarães (n. ${ }^{\text {os }}$ 169, 180, 186, 196 e 223 do inventário de VAZ: 1993).

O destino das villae romanas viseenses, na generalidade, porém, parece ter sido outro: transformarem-se em quintas. Com efeito, das 17 villae identificadas por João Vaz no concelho de Viseu (16, mais o número 186, que parece dever identificar-se também como uma villa), 10 correspondem a modernas quintas. Tal como, no Alentejo, as villae romanas deram lugar a "montes", no território de Viseu muitas delas transformaram-se em quintas.

Se, das aldeias em redor de Viseu mencionadas no séc. XII, apenas duas parecem ter surgido de villae romanas, temos de procurar outro(s) processo(s) de formação das aldeias.

Numa segunda hipótese, as aldeias teriam surgido de casais romanos, pelo progressivo crescimento do núcleo familiar original. Se admitirmos um crescimento anual positivo de $4,8 \%$ c, uma família de cinco membros daria origem, ao fim de 390 ou 400 anos, a um lugarejo de uma trintena de vizinhos (ALARCÃO, 1996; mas vid. DuBY (1980: 198) sobre um crescimento medieval de $2,8 \% \mathrm{c}$ ). Um casal fundado no séc. I d. C. poderia, no séc. V, ser já um lugarejo; e, com o correr dos tempos, eventualmente pela imigração de alguns, teria dado lugar, no séc. XII, a uma aldeia.

Neste caso deveríamos encontrar vestígios romanos nessas aldeias. Isso não se verifica, o que parece excluir este processo de formação. O rigor da conclusão, porém, é apenas aparente, porque os 
dados não são inequívocos. Uma aldeia surgida progressivamente de um casal na sua origem romano, dada a modéstia das construções que este teria e a pobreza da cultura material dos seus moradores, pode não apresentar hoje vestígios romanos facilmente detectáveis. Por outro lado, como se deduz da tese de João Vaz, muitas das aldeias actuais do território de Viseu parecem apresentar vestígios romanos em locais sitos num raio de 15 minutos a partir do centro da povoação actual. Este processo de derivação das aldeias afigura-se-nos, pois, possível para explicar alguns dos povoados actuais mas não todos, seguramente; e sobretudo não explica as aldeias citadas na documentação do séc. XII.

O problema, pois, permanece: muitas das aldeias do séc. XII aparentam ser povoações novas. Donde teria vindo a população?

Talvez, onde houve castros, como na região de Lafões e no concelho de Castro Daire, estes tenham sido abandonados na Alta Idade Média e, em seu lugar, se tenham formado aldeias. Mas este não é o caso da área a ocidente de Viseu, porque aqui não temos castros: o de Santa Luzia, a norte de Viseu, parece ter sido abandonado na época romana, a favor de Viseu. Terá vindo de fora a população que fundou as aldeias? Terão estas resultado de um êxodo urbano que instalou nos campos uma população previamente moradora na cidade?

Ambos os processos nos parecem viáveis. A imigração, para o território de Viseu, após a conquista de Fernando Magno (1057 ou 1058), de gentes estabelecidas na sempre instável zona de fronteira, é uma hipótese a ter em consideração. No concelho de Mangualde, uma aldeia chamada Ançada parece ter-se formado desta maneira (FERNANDES, 1989: 363-364 sobre a explicação do topónimo: Anaziada> Aançada $>$ Ançada. O "anaziado" era o que passava de um a outro campo, dos mouros para os cristãos ou destes para aqueles, como se depreende do foral de Seia).

Também não podemos esquecer a remissão de cativos, trocados por dinheiro ou por servos mouros (DMP, DP IV, n. ${ }^{\circ} 1$ ). Que fariam os senhores promotores desta remissão aos cativos que chegavam? Podiam talvez ajudá-los a instalarem-se em aldeias novas.

Se as aldeias viseenses do séc. XII se formaram com uma população vinda de fora ou da cidade, após a conquista de Fernando Magno, terá sido esta "colonização ruraf"um fenómeno espontâneo ou organizado por alguns senhores? A segunda hipótese não nos parece inviável (DubY, 1987 (2): 99 e 105, sobre a acção conjunta dos camponeses e 
senhores nos arroteamentos europeus do séc. XII); mas a associação espontânea é igualmente credível (DUBY, 1987 (1): 104).

A doação, por D. Henrique e D. Teresa, aos presbíteros João Siiciz e Fáfila, da herdade de S. Romão (Seia) para a povoarem (DMP, DR I, n. $\left.{ }^{\circ} 10\right)$ é um testemunho da acção organizada de repovoamento em terras anteriormente de fronteira.

A documentação do séc. XII mostra senhores na posse de villae (=aldeias). Tomemos por exemplo D. Gonçalo, bispo de Coimbra, senhor das villae de S. João das Areias (conc. de Santa Comba Dão), Parada e Oliveira de Cúrrelos (conc. de Carregai do Sal), que deixa, por sua morte, ao cabido (DMP, DP IV, n. ${ }^{\circ}$ 6). Como adquiriu o bispo a posse das aldeias?

Não terá sido porque as fundou, atraindo povoadores que se tornaram seus foreiros? Mas D. Gonçalo deixa ao cabido aquelas aldeias salvo a parte que nelas tinha Garcia Sendiniz. Quem seria este Garcia? Senhor parceiro do bispo na instalação dos colonos, e por isso coproprietário, isto é, co-recebedor das rendas?

A fundação de aldeias por iniciativa de senhores pode constituir uma explicação para as situações de copropriedade de aldeias que se observa (v. g. DMP, DP IV n. ${ }^{\text {s }} 86,87$ e 116): os direitos do(s) fundadores) e primeiro(s) proprietário(s) ir-se-iam fragmentando por virtude de sucessões e partilhas.

Para além deste problema da origem das aldeias viseenses, temos de pôr um outro: por que razão está o território vazio de aldeias a oriente e a sul?

A nordeste, entre Barreiros, AI velos e Travancela, é ainda grande o número de aldeias, na sua maior parte provavelmente na órbita do Sátão, que recebeu foral em 1111: Sátão seria o seu centro económico e religioso. Mas entre Viseu e Povolide não há aglomerado algum. Observemos que, na época romana, a área está igualmente deserta. Residirá num solo pouco fértil a razão deste ermo nas duas épocas? Mas seria originariamente mais fértil a área a ocidente da cidade? A maior fertilidade actual dessa área a ocidente não será um produto da actividade humana desde o séc. XII? Só um pedólogo nos poderia esclarecer. E a ausência de povoamento entre Viseu e Povolide não será mera aparência resultante da perda de documentos? Não deixa todavia de ser singular a referência a montes e rios no território de Lafões, contraposta à ausência destas referências geográficas nos documentos que se reportam ao território de Viseu, como se rios e montes não estivessem ainda nomea- 
dos (por falta de povoamento). Mas não derivará esta diferença de um simples estilo dos notários?

A Sul, no vale médio do Dão, entre Fragosela de Baixo e Loureiro de Silgueiros, o problema é diferente: também aqui não temos aldeias mas observamos diversas villae e casais romanos. A infertilidade dos solos não parece, assim, constituir a explicação para a ausência de aldeias.

As villae e os casais romanos podem ter aqui sobrevivido, sem rasto documental, até ao séc. XII. Mas, mesmo admitindo esse facto, a capacidade de sustentação do território não estava certamente esgotada. Se as villae do território viseense tinham, como atrás supusemos, fundi de 50 hectares, haveria muita terra livre para instalação de aldeias. Só no caso de as villae terem cerca de 900 hectares estaria o território totalmente ocupado.

Não nos parece de todo em todo inviável um crescimento considerável dos fundi no Baixo Império ou na Alta Idade Média. "No séc. $\mathrm{X}$ começa, pelo menos na Itália, o assalto feudal ao bosque, a privatização dos espaços incultos, a criação de reservas de caça controladas pelos potentes" (BARCELÓ et olii, 1988: 214).

No vale médio do Dão, a apropriação dos baldios e o crescimento das villae com o objectivo de se criarem grandes coutadas não nos parece muito convincente. Terão os senhores apropriado os baldios para manterem grandes rebanhos de ovicaprinos e varas de suínos de cuja lã e couros tirariam rendimento superior ao que obteriam da concessão de terras a "colonos"? Mas por que razão não encontramos, na documentação do séc. XII, traço destes eventuais grandes senhores do médio Dão? Porque a documentação desapareceu?

Analisaremos mais adiante a zona sudoeste da nossa carta 2.

\section{Na Região de Lafões}

A área de Lafões (carta 3) mostra-se, no séc. XII, densamente ocupada; e também aqui há lugares documentalmente atestados que não conseguimos identificar.

Talvez uma parte das aldeias tenha resultado do abandono dos castros: os de Paços de Vilharigues ( $\mathrm{.}^{\circ}$ 1) e de Pinho (n. ${ }^{\circ}$ 7) poderão ter dado origem às aldeias do mesmo nome; o da Senhora do Castelo (n. ${ }^{\circ}$ 2), a Vouzela. Os lugares romanos não parecem ter dado origem a 
aldeias. Também aqui elas são fundações novas, muitas das quais se desenvolvem em terrenos xistosos das margens do rio Vouga, mais férteis que os graníticos.

$\mathrm{O}$ vicus das Termas de $\mathrm{S}$. Pedro do Sul não só se manteve como conservou a sua importância regional, pois recebeu foral de D. Afonso Henriques em 1152.

A parte ocidental da área parece menos habitada. Terá sido em terras ermas que surgiu o mosteiro de S. Cristóvão de Lafões, fundado ou reformado por D. João Peculiar antes de 1137, ano em que D. Afonso Henriques lhe fez doação do couto de Valadares, hoje, Couto de Baixo (DPM, DR 1(2): 649-650); o mesmo rei, em 1161, doou-lhe o couto de Trapa e Paço, depois conhecido por Couto de Cima. É provável que o mosteiro tenha tido papel importante no repovoamento da área; mas o seu cartório, infelizmente, perdeu-se, consumido por incêndios.

Até aos finais do séc. XI temos notícia de Oliveira (de Frades?), Villa de S. Vicente, Cercosa, Vouzela, Várzea, Segadães, Figueirosa, S. Pedro do Sul, Bordonhos, Nespereira, Santa Cruz e Abados (MERÊA e GIRÃO, 1943). As demais localidades registadas na nossa carta surgem no séc. XII.

\section{No Alto Paiva}

A região do Alto Paiva (carta 4), onde os castros se mantiveram na época romana, donde as villae estão quase ausentes e onde os casais romanos são raros (excepto na limitada área de Ferreira de Aves), desenvolveu-se assimetricamente na Alta Idade Média. A parte oriental, em tomo de Vila Nova de Paiva, parece de desenvolvimento tardio, embora haja aí algumas pequenas estações romanas que João Vaz não localizou (MARQUES, 1992).

A parte ocidental, correspondente ao concelho de Castro Daire, era no séc. XII conhecida como território de Penafiel ou Penafiel de Covas (MERÊA e GIRÃO, 1943) e já razoavelmente ocupada. São várias as localidades mencionadas até ao séc. XI: Janarde, Covelo, Cabreiros, Meitriz, Sequeiros, Nodar, Avó, Grijó, Reriz, Covas do Monte, Covas do Rio, Pena, Posmil, Macieira e Gafanhão. Outras aparecem pela primeira vez citadas em documentos de 1101-1123: Deilão, Sete Fontes, Ester, Sá, S. Martinho das Moitas e Folgosa. Há ainda, em documentos do séc. XII, lugares que não conseguimos identificar. 
Não sabemos se, no séc. XII, Solgos era aldeia. No séc. XIII formava reguengo com Reriz. D. Afonso Henriques, em data incerta, doou aos monges de S. Miguel de Riba de Paiva (freguesia de Real, concelho de Castelo de Paiva) dois casais desse seu reguengo (DMP, DR 1(2): 533).

D. Egas Moniz teve as "honras" de Gosende, Mezio, Vale do Conde (= Vale Abrigoso), Mões e Moledo (CORREIA, ALVES e VAZ, 1986: 41) e D. Afonso Henriques, entre 1139 e 1162, confirmou as duas últimas a D. Moço Viegas, filho de D. Egas Moniz (DPM, DR 1(2): 536).

Ainda no séc. XII existiam, a noroeste de Castro Daire, a freguesia de S. João do Pinheiro e o mosteiro da Ermida (CORREIA, ALVES e VAZ, 1986: 43).

D. Henrique (1095-1112) deu foral a S. Martinho de Alva (DPM, DR 1(2): 515), hoje Alva (que tem S. Martinho por orago), e D. Afonso Henriques, a Castro Daire (DPM, DR, 1(2): 533). Ambos os documentos se perderam.

O mesmo adensamento da população que, antes de 1123 , observamos no território de Lafões verifica-se no de Penafiel. A estreita relação das duas áreas está aliás testemunhada pelo facto de o antigo território de Penafiel aparecer, em documentos do primeiro quartel do séc. XII, por vezes designado como território de Lafões. E um notável da época, João Gondesendes, teve bens nos dois territórios (VENTURA, 1985).

É possível que se tenha estabelecido uma estrada de Castro Daire a S. Pedro do Sul, estrada de cuja origem romana não temos prova: poderá ter surgido apenas no séc. XI ou XII. Ignoramos ainda se a estrada descia de Castro Daire por Alva e Figueiredo de Alva ou se subia por Sul e Gafanhão até Reriz.

Um outro caminho devia ligar Castro Daire a Arouca. E ao longo desta segunda via que o povoamento se desenvolve. A antiga via romana de Viseu a Castro Daire, curiosamente, não parece ter atraído povoamento. O antigo vicus que presumimos em Lamas de Moledo deve ter persistido, ainda que não haja, até 1123, referências documentais.

Muito diferente se apresenta a área entre Castro Daire e Vila Nova de Paiva. A quase total ausência de documentação até 1123 (só um documento de D. Teresa, de 1128, se refere a Fráguas, que mais tarde se tomaria concelho, GEPB, voc. Vila Nova de Paiva) sugere uma área paralisada, onde talvez os antigos castros de S. Lourenço (n. $\left.{ }^{\circ} 15\right)$, Vila Cova-à-Coelheira (.$^{\circ}$ 16) e Santa Bárbara (n. ${ }^{\circ}$ 17) tenham permane- 
eido. Surgem todavia as "honras" de Mões e de Moledo que, como vimos, pertenceram a D. Egas Moniz (? - 1146).

$\mathrm{Na}$ área de Ferreira de Aves, onde o povoamento era disperso, surgiu um aglomerado urbano: o de Ferreira de Aves, ao qual D. Teresa deu foral entre 1112 e 1120 (DPM, DR 1(2): 578; FERNANDES, 1990: 65) e onde, antes de 1163, se instalou um mosteiro que se tomaria importante. Mas, para além da sede de concelho, surgiram também aldeias: em 1124, D. Teresa fez doação de uma herdade em Pereira, in termino de Castaneira per cima de Lamosa (DPM, DR 1(2): ref. 8). Pereira terá sido aldeia, bem como Castanheira e Famosa? Em 1128, D. Teresa couta Fráguas a Garcia Garcês.

\section{O Alto Dão}

Em Aguiar da Beira (carta 5) talvez tenha existido, na época romana, um vicus ou, pelo menos, estação de muda na estrada romana que, de Mangualde, se dirigia a civitas Aravorum (Marialva) ou a Meidobriga (na área da Meda). A povoação recebeu foral em 1157.

$\mathrm{Na}$ área de Sátão deve também ter existido um vicus ou estação de muda, na mesma estrada de Mangualde a Aguiar da Beira, a meio caminho. Não sabemos, porém, onde localizá-lo. Talvez nas imediações de Silvã de Cima; a verdade, porém, é que nenhuma das estações conhecidas na área aparenta ter sido vicus, mansio ou mutatio. Numa zona de povoamento romano disperso, tal corno a de Ferreira de Aves, surgiu igualmente um aglomerado urbano, aliás perto do antigo castro romanizado dos Santos Idos: Sátão. Povoação de origem muçulmana (,Zalatane > Zalatam> Zátão > Sátão), recebeu foral em 1111, contemporaneamente a Chãs de Tavares.

$\mathrm{Na}$ área de Sátão surgem numerosas aldeias, num povoamento similar, ainda que menos denso, ao que encontrámos na área a ocidente de Viseu. Parece-nos isso prova do dinamismo da povoação e da política de repovoamento dos condes.

Por S. Miguel de Vila Boa passava uma estrada que ia a Bacim, Famaçais e Silvares e daí, a Viseu. Não temos prova de que essa estrada fosse romana, mas isso não é impossível.

Não sabemos se, no primeiro quartel do séc. XII, já existia Rio de Moinhos, que recebeu foral de D. Sancho I (GEPB, voc. Rio de Moinhos; mas na documentação publicada de D. Sancho não se encontra o foral). 
A área de Penalva do Castelo, mais uma vez, apresenta, na época romana, um povoamento disperso e sem aglomerado urbano. Mas Penalva do Castelo existia já em 1057 ou 1058, data em que Fernando Magno tomou o castelo (GEPB). O foral de Azurara da Beira (1109) cita Penalva como confim de Mangualde. Ao contrário de Sátão, Penalva do Castelo não parece ter atraído povoamento para a sua área.

Outro aglomerado urbano relativamente importante na Idade Média foi Algodres, que recebeu foral talvez de D. Sancho (MARQUES, 1938: 295; mas entre a documentação publicada de D. Sancho I não se encontra tal foral). Uma ara anepígrafa conservada na residência paroquial e alguma cerâmica achada no Largo da Igreja deixam presumir a origem romana da povoação; mas nada permite suspeitar de um aglomerado urbano na época romana: talvez só villa (se bem que João Vaz situe aí apenas um casal; mas não seria antes uma villa?).

Em 1146, D. Afonso Henriques vendeu a herdade de Figueiró da Granja, que lindava com Celorico da Beira, Algodres, Fomos de Algodres e Liares: é uma das raras vastíssimas propriedades de que temos notícia na Beira Central (DPM, DR 1(1): 264; DPM, DR I (1): 403).

$\mathrm{Na}$ estrada romana de Mangualde a Celorico da Beira, uma paragem fazia-se provavelmente em Chãs de Tavares. Junto ao castro situa-se uma estação romana que João Vaz interpretou como villa. Não será antes uma mansio ou mutatio, junto da qual pode ter surgido um pequeno aglomerado? Este terá persistido na Idade Média e chegado até aos nossos dias. O certo é ter sido Chãs de Tavares sede de um concelho. O foral data de 1111 ou 1112 (DPM, DR 1(2): 568-569). Tal como Penalva do Castelo e Algodres, também Chãs de Tavares não atraiu povoamento. Talvez Travanca de Tavares tenha surgido de uma villa romana.

Finalmente, chegamos à área de Mangualde. Núcleo urbano importante na época romana, manteve na Idade Média a sua capitalidade e foi sede de um concelho que o conde D. Henrique criou em 1109 (DMP, DR 1(2): 561; FERNANDES, 1991: 235). Chamou-se então Azurara e foi cabeça de uma terra que já no séc. XI tinha nome de Zurara ou Azurara (MERÊA e GIRÃO, 1943). Entre 1121 e 1128, provavelmente em 1128, o conde Fernando Peres de Trava sancionou o foral.

Em 1154 temos notícia do mosteiro de Maceira Dão em documento de D. Afonso Henriques. O mesmo rei, em 1161, concedeu a este mosteiro o couto de Santa Maria de Moimenta, que confinava 
com Lobelhe do Mato, Argeriz, Água Levada e Pinheiro. Em 1173, D. Afonso Henriques coutou ao mosteiro a área em redor do convento.

Em conclusão:

No Alto Dão mantêm-se dois aglomerados urbanos de época romana, que se tomam sedes de concelhos: Chãs de Tavares e Mangualde. Criam-se novos aglomerados, também sedes de concelhos: Penalva do Castelo, Sátão e Algodres, este último talvez com origem nuna villa romana. Aguiar da Beira poderá ter nascido também num lugar ocupado na época romana.

Sátão e Mangualde manifestam, particularmente a primeira, uma certa vitalidade, enquanto Aguiar da Beira, Penalva do Castelo, Algodres e Chãs de Tavares revelam pouco poder de atracção. Realidade ou visão distorcida, baseada numa documentação desequilibrada?

Os concelhos formam-se ao longo das antigas vias romanas. Entre elas, a oriente de Penalva do Castelo, permanece um espaço ermo, onde mais tarde (quando?) surgiria o concelho de Penaverde.

De todas as localidades citadas, a maior, nos inícios do séc. XVI, é Penalva do Castelo, com 764 fogos. Sátão tem então 364; Algodres, 357; Mangualde e Chãs de Tavares, 311; Penaverde, 178; Aguiar da Beira, 78 (GAlego e Daveau, 1986).

\section{No território de Senhorim}

Entre o Alto e Baixo Dão (carta 2) intercala-se uma zona que, na Idade do Ferro, não parece ter sido povoada. Na Alta Idade Média era o território de Senhorim, cuja cabeça estaria mesmo em Senhorim.

A área não tinha, na época romana, nenhum aglomerado urbano. A fundação de Senhorim deve remontar à Alta Idade Média. Mas, se não há vestígios romanos mesmo em Senhorim, estes encontram-se muito perto, na encosta de Casal Sandinho, sobre o rio Videira.

É escassa a documentação até ao séc. XII. Santar, Vilar Seco e Moreira de Cima (ou a sua homónima de Baixo, aliás muito vizinha) existiam já no séc. XI (MERÊA e GIRÃO, 1943). Em 1102 cita-se Travassos (talvez na freguesia de Carvalhal Redondo, concelho de Nelas) e em 1103 volta a mencionar-se Moreira. Em 1123 aparece referência a villa Branido e a Bena Gamus (DPM, DP IV(1): 308), que também não sabemos identificar. Em 1155, Canas de Senhorim (LIVRO SANTO DE SANTA CRUZ, n. ${ }^{\circ}$ 201), cujos povoadores recebem, em 1196, carta de 
foro (LOUREIRO, 1957: 315; mas na documentação publicada de D. Sancho não se encontra tal carta).

\section{$\mathrm{Na}$ área de Tondela}

A população da área de Besteiros/Tondela (carta 6), na época romana, continuou a viver nos castros: são raros os casais e as villae identificados na área. O panorama é de urna zona marginal.

Até finais do séc. XI não se conhece qualquer documentação. Mas nem no séc. XII a área parece ter atraído povoamento significativo. Os documentos mencionam todavia diversos lugares, alguns dos quais não sabemos identificar: marcámos apenas os que reconhecemos; mas onde ficariam Figueiró, Canelas, Sobradinho, S. João do Monte, Comias e Vale? S. João do Monte é hoje nome de freguesia do concelho de Tondela mas não existe propriamente aldeia ou vila com este nome.

\section{Na área do Mondego à Serra da Estrela}

O território entre o Mondego e a Serra da Estrela (carta 7) constituiu talvez, no período suévico, a freguesia que o Paroquial Suévico designa por Subverbeno ou Suberbeno (corruptela de Subhermenol).

No séc. XI, os documentos falam do território de Seia ou Sena, que, na primeira metade do séc. XII, ia, a norte, pelo menos até Paços da Serra e vinha, a oeste, até Midões (concelho de Tábua), conforme se deduz da documentação reunida no LIVRO SANTO DE SANTA CRUZ (vid. também MERÊA e GIRÃO, 1943). O território de Seia ultrapassava, pois, o antigo termo da civitas romana de Viseu e entrava no da civitas de Bobadela.

O povoamento medieval concentra-se entre Seia e Midões. O vazio de estações romanas é ilusório. João Vaz não fez aí prospecções, porque, para ele, o território já não era de Viseu. Estamos certos de que uma prospecção sistemática descobrirá aí estações romanas.

Seia foi conquistada aos Mouros em 1055 (COELHO, 1990: 122) e tomou-se cabeça de território. Não há notícia de achados romanos em Seia, a não ser no campo de futebol (ALARCÃO, 1993: 16). Perto da cidade, na Quinta da Nogueira, há vestígios romanos. Ainda que Bigotte (1981: 46) indique, como área de dispersão dos achados, uma superfície 
(muito considerável) de 6 hectares, temos relutância em admitir aqui um vicus, tão próximo (a 2,5 quilómetros) do castro romanizado de S. Romão. Não poderão os vestígios corresponder a uma villa e a alguns casais? Será a área dos achados contínua?

Seia surge numa área romanizada mas parece uma fundação alto-medieval. Temos dúvidas sobre se a Sena citada na Divisio Wambae (in LIBER FIDEI, n. ${ }^{\circ}$ 9) como limite da diocese egitaniense se pode ou deve identificar com Seia. Parece-nos muito difícil admitir que a diocese da Egitânia ultrapassasse o festo da Serra da Estrela e viesse até à sua vertente ocidental.

A povoação de S. Romão, onde se ergueu uma igreja dependente de Santa Cruz de Coimbra, é conhecida desde 1106. Ou, mais correctamente, desde 1106 é conhecida a herdade de S. Romão, iusta Senam. Nesta data, D. Henrique e D. Teresa doam aos presbíteros João Siiciz e Fáfila a herdade chamada de S. Romão, com seus termos antigos, para que a povoem, edifiquem aí casas e plantem vinhas (ut ambo populetis illam et secundum possibilitatem vestram hedificetis ibi domos et plantetis vineas, LIVRO SANTO DE SANTA CRUZ; n. ${ }^{\circ} 70$ ). Seria essa herdade uma antiga villa romana abandonada? e abandonada desde quando? ou simplesmente degradada?

Os presbíteros instalam na herdade um mosteiro com sua igreja, talvez no antigo paço romano; e chamam povoadores. Talvez a uns tenham distribuído prédios foreiros; a outros, alodios; a outros, ainda, prédios simplesmente onerados com o tributo da calúnia. Dos segundos serão exemplos as herdades de Paio Gontiges e Mem Mazon (LIVRO SANTO, n. ${ }^{\circ} 78$ e 79); dos últimos, a herdade de Pedro Nunes, Diogo Aredaz, João Peres e Pedro Pais (LIVRO SANTO, n. ${ }^{\circ} 80$ ).

Os povoadores atraídos pelos presbíteros terão construído suas moradas junto ao mosteiro, criando assim uma aldeia, sem prejuízo de um povoamento disperso que pode ter-se verificado ao mesmo tempo.

Entretanto, em Assamassa (hoje Catraia) havia-se formado outra aldeia, na qual conhecemos vários proprietários (LIVRO SANTO, n.os 82, 87,89 e 97). Talvez a "herdade" a que se refere o documento n. ${ }^{\circ} 87$ não fosse uma herdade possuída por três casais, mas correspondesse a três herdades; da mesma maneira, no doc. n. ${ }^{\circ}$ 97. Esta aldeia veio a ficar dependente de S. Romão, porque o documento n. ${ }^{\circ} 87$ do LIVRO SANTO chama, a Assamassa, loco in villa Sancti Romani.

Em data incerta, mas antes de 1137, Fáfila doa metade da herdade ao presbítero Pedro que, em 1137, faz testamento dessa sua metade ao 
mosteiro de Santa Cruz de Coimbra (Livro SANTO, n. ${ }^{\circ}$ 72); e, em 1138, João Siiciz (no documento n. ${ }^{\circ} 71$ do LIVRO SANTO, agora chamado João Ciiz) doa a parte que lhe cabia da dita herdade, isto é, a outra metade, ao mesmo mosteiro de Santa Cruz.

Ainda no mesmo ano de 1130, D. Afonso Henriques delimitou a Santa Cruz o couto de S. Romão (LIVRO SANTO, n. ${ }^{\circ}$ 8); supomos que ia da confluência da ribeira de Paramol com o Alva, talvez por Senhora de La Salette, até Nogueira, descia pelas ribeiras do Barbil e do Crestelo até Crestelo, subia a Golias, ia à Quinta de Vale de Caminhos, à Catraia e descia até ao Alva, que constituía o limite meridional. Nas Inquirições de D. Afonso III (PM, INQ. 1(2): 773) citam-se, porém, limites mais vastos, que hão-de corresponder a uma nova demarcação de D. Afonso Henriques ou de D. Sancho I.

Nos meados do século XII, o território de Seia era medianamente povoado: a localidade de S. Paio (a norte de Gouveia, talvez já fora do território) está atestada desde 1128 (DMP, DR 1(2): 517); Assamassa (a identificar com Catraia), desde 1138; ainda desde 1138, Cástrelo (= Quinta do Crestelo?), Lagos da Beira, Lajeosa, Meruge, Nogueira, (= Quinta da Nogueira?), Paramol (na confluência da ribeira deste nome com o Alva?), Travanca, Torrozelo, Vila Cova (à-Coelheira); Aldiam (entre o rio Torto e Arcozelo, talvez já fora do território de Seia), desde 1140; Travancinha, ainda desde 1140; Valezim, desde 1141; Santa Eulália e Nogueirinha, desde 1142; Vila Nova (perto de Ervedal), desde 1146; Santa Marinha, desde 1147; Sandomil, desde 1148; Paços da Serra, desde 1150; Souto Maior (perto de Sandomil), desde 1152; Alvariça (algures entre Lagares e Travanca de Lagos), desde 1155. O Livro Santo de Santa Cruz, donde retirámos estas informações, menciona ainda outras localidades que não sabemos identificar.

Seia, com um vasto território que ia do Mondego ao Zêzere, foi doada em 1122 por D. Teresa a Fernando Peres de Trava, e recebeu foral em 1136; Gouveia, que aparece pela primeira vez citada em 1141, recebeu foral em 1186.

\section{Conclusão}

$\mathrm{Na}$ região correspondente à antiga civitas romana de Viseu, os castros constituem grupos que procurámos individualizar. A cada grupo

Conimbriga, 35 (1996) 5-35 
de castros corresponderia uma unidade étnica que tentámos identificar, recorrendo à epigrafia romana. O importante castro de Santa Luzia, bem no centro do território, poderá ter exercido funções de lugar central, o que justificaria a instalação, perto dele, do acampamento romano da Cava de Viriato, e depois, de Viseu, capital da civitas romana.

$\mathrm{Na}$ época romana manteve-se a maioria dos castros. Alguns, como Castro Daire, Chãs de Tavares, Mangualde, Folgosinho e Gouveia, tornar-se-iam sedes de concelhos medievais.

Ainda na época romana, criou-se um vicus em torno das Termas de S. Pedro do Sul, que se manteve até aos nossos dias.

Excluídos os castros, as aldeias parecem inexistentes na época romana: o povoamento dispersa-se por villae e, sobretudo, casais. Ora, nos séculos XI e XII, são numerosas as aldeias, particularmente a ocidente de Viseu e na região de Lafões, bem como nas áreas de Castro Daire e de Sátão. A maior parte das aldeias não aparenta ter surgido de villae ou casais romanos; parece ser fundação nova.

Mas, se muitas das aldeias dos séculos XI e XII são novas (relativamento ao povoamento romano), que destino tiveram as antigas villae e os casais da época romana? Mantiveram-se, num povoamento disperso perfeitamente compatível com os aldeamentos? Parece difícil responder a esta questão. Mas não nos parece necessário admitir o ermamento de villae e casais por parte de uma população que se teria concentrado em aldeias; é perfeitamente admissível que as aldeias se tenham acrescentado a um povoamento disperso, isto é, que villae e casais de origem lusitano-romana se tenham mantido. Nesse sentido fala o facto de 10 das 17 villae do concelho de Viseu corresponderem a quintas actuáis que seriam, assim, as herdeiras do habitat romano.

$\mathrm{O}$ achado de materiais romanos perto de muitas aldeias actuais (de cuja existência se deverão procurar provas na documentação posterior a 1123 e na do séc. XIII, designadamente nas Inquirições) deixa supor que essas aldeias derivam de casais romanos, com pequena deslocação do lugar da implantação.

BIBLIOGRAFIA

AlarCão, Jorge de, 1989: A cidade romana de Viseu, Viseu.

AlarCão, Jorge de, 1989 a: "Geografia política e religiosa da civitas de Viseu", in Actas do l. $^{\circ}$ Colóquio Arqueológico de Viseu, Viseu: 305-314.

Conimbriga, 35 (1996) 5-35 
AlarCãO, Jorge de, 1993: Arqueologia da Serra da Estrela, Manteigas.

ALARCÃo, Jorge de, 1996: "Os círculos culturais da Ia. Idade do Ferro no Sul de Portugal", in F. Vilar e J. ENCARNaÇão (eds. ), La Hispania prerromana. - Actas del VI Coloquio sobre Lenguas y culturas prerromanas de la Peninsula Ibérica, Salamanca/Coimbra, 1996: 19-36.

Alarcão, J. ; Etienne, R. ; Mayet, F. , 1990: Les villas romaines de São Cucufate (Portugal), Paris.

Amaral, Paulo, 1993: O povoamento no vale superior do Tâmega. Permanencias e mutações na humanização de uma paisagem, Porto (tese de mestrado, policopiada).

Aragão, Maximiano d', 1894: Vizeu. Apontamentos históricos, Viseu.

AZevedo, Luís Gonzaga de, 1939-1940: Historia de Portugal, 2(1939) e 3(1940), Lisboa.

Azevedo, Rui de; Costa, Avelino de Jesus da; Pereira, Marcelino Rodrigues, 1979: Documentos de D. Sancho I (1174-1211), Coimbra.

BARCElÓ, Miquel et alii, 1988: Arquelogia medieval. En las afueras del "medievalismo", Barcelona.

BIGOTTE, J. Quelhas, 1981: Monografia da cidade e concelho de Seia, Seia (Ia. edição em 1945).

BRAÑas, Rosa, 1995: Indixenas e Romanos na Galicia céltica, s. 1. (Librería Follas Novas).

Coelho, María Helena da Cruz, 1990: Homens, espaços e poderes. Séculos XI-XVI. I. Notas do viver social, Lisboa.

Correia, Alberto; Alves, Alexandre; VAZ, João L . Inés, 1986: Castro Daire, Castro Daire.

CuRAdo, Fernando, 1989: "As inscrições indígenas de Lamas de Moledo (Castro Daire) e do Cabeço das Fráguas, Pousafoles (Sabugal): duas teogonias, diferente etnogénese?", in Actas do l. $^{\circ}$ Coloquio Arqueológico de Viseu, Viseu: 349-370.

DMP, DP: Documentos Medievais Portugueses, Documentos Particulares, III, A. D. 1101-1115, Lisboa, 1940; IV, A. D. 1116-1123, Lisboa, 1980.

DMP, DR: Documentos Medievais Portugueses: Documentos Régios, vol. I, Documentos dos condes portugalenses e de D. Afonso Henriques, A. D. 1095-1185, 2 tomos, Lisboa, 1962.

Duby, Georges, 1911 . La société au XIe et XIIe siècles dans la région mâconnaise, Paris.

Duby, Georges, 1980: Guerreiros e camponeses. Os primórdios do crescimento económico europeu, séc. VII-XII, Lisboa.

Duby, Georges, 1987 e 1988: Economia rural e vida no campo no Ocidente medieval, I (1987) ell (1988), Lisboa.

Fernandes, A. de Almeida, 1967: "Paróquias suevas e dioceses visigóticas", Arquivo do Alto Minho, 15: 5-57.

FernandeS, A. de Almeida, 1989: "A toponímia da Beira Alta", Beira Alta, 48(3-4): 357-386.

Fernandes, A. de Almeida, 1990-1991: "Viseu, Agosto de 1109. Nasce D. Afonso Henriques”, Beira Alta, 49(1-2), 1990: 29-78; 49(3-4), 1990: 311-346; 50(1-2), 1991: 179-213; 50(3), 1991: 221-282.

Conimbriga, 35 (1996) 5-35 
FrEUND, Bodo, 1974: "L'ancien cadastre de Vilaça. Étude méthodique sur l'évolution d'un village du nord du Portugal", Finisterra, 9(17): 51-74.

Galego, Julia e Daveau, Suzanne: O Numeramento de 1527-1532. Tratamento cartográfico., Lisboa.

GarCIA DE CORTÁZAR, José Angel, 1983: História rural medieval, Lisboa.

GEPB: Grande Enciclopédia Portuguesa e Brasileira, Lisboa e Rio de Janeiro.

GIRÃo, Amorim, 1933: Esboço duma carta regional de Portugal, Coimbra.

Lema, Paula Bordalo, 1978: Tourém. Uma aldeia raiana do Barroso, Lisboa.

LEMos, Francisco de Sande, 1993: Povoamento romano de Trás-os-Montes, Braga (dissertação de doutoramento, policopiada).

Lévi-Provençal, E. , 1950: Histoire de T Espagne musulmane, 1 e II, Paris.

Liber Fidei Sanctae Bracarensis EcClesiae, ed. Avelino de Jesus da Costa, tomo I, Braga, 1965.

Livro Santo de Santa Cruz, lido e anotado por Leontina Ventura e Ana Santiago Faria, Coimbra, 1990.

Loureiro, José Pinto, 1957: Concelho de Nelas (Subsídios para a história da Beira) Nelas.

MARQUES, Jorge Adolfo de Meneses, 1992: "Notas arqueológicas do concelho de Vila Nova de Paiva", Beira Alta, 51(3-4): 359-382.

Marques, Monsenhor Pinheiro, 1930: Terras de Algodres (Concelho de Fornos), Lisboa.

MateU Y Llopis, Felipe, 1936: Las monedas visigodas del Museo Arqueológico Nacional, Madrid.

MERÊA, Paulo e GIRÃO, Amorim, 1943: "Territórios portugueses no séc. XI", Revista Portuguesa de Historia, 2: 255-263.

PEDRo, Ivone, 1995: O povoamento proto-histórico na região de Viseu, Porto (dissertação de mestrado, policopiada).

SÁEz, Emilio, 1947: "Ramiro II, rey de Portugal de 926 a 930", Revista Portuguesa de Historia, 3: 271-290.

Silva, Valentim da, 1978: Concelho de Mangualde (antigo concelho de Azurara da Beira), Viseu.

VAz, João L. Inês, 1993: A civitas de Viseu (Espaço e sociedade), Coimbra (tese de doutoramento, policopiada).

VentURA, Leontina, 1985: "O cavaleiro João Gondesendes. Sua trajectória político-social e económica (1083-1116)", Revista de História Económica e Social: 31-69.

Conimbriga, 35 (1996) 5-35 
CARTA 1

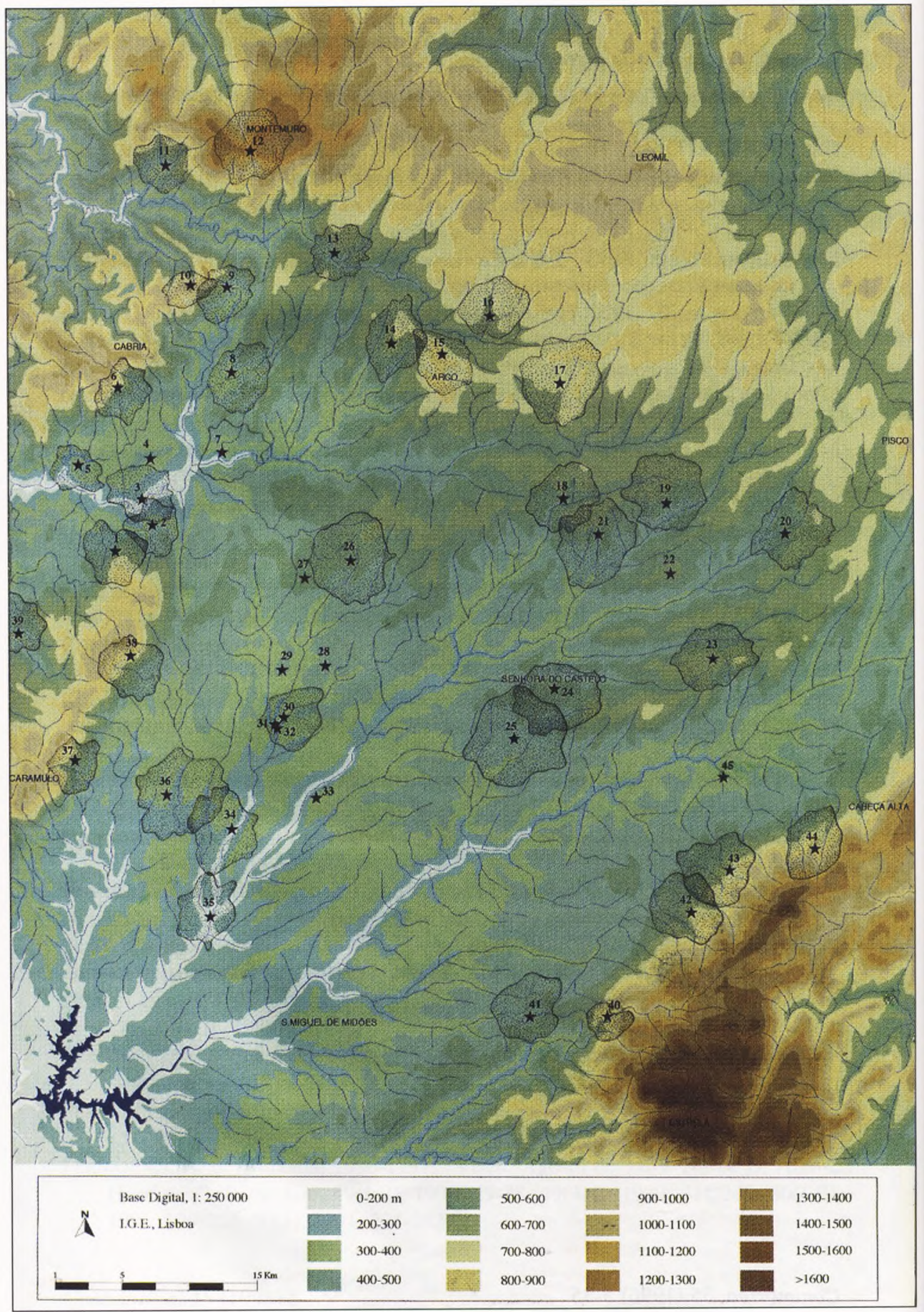




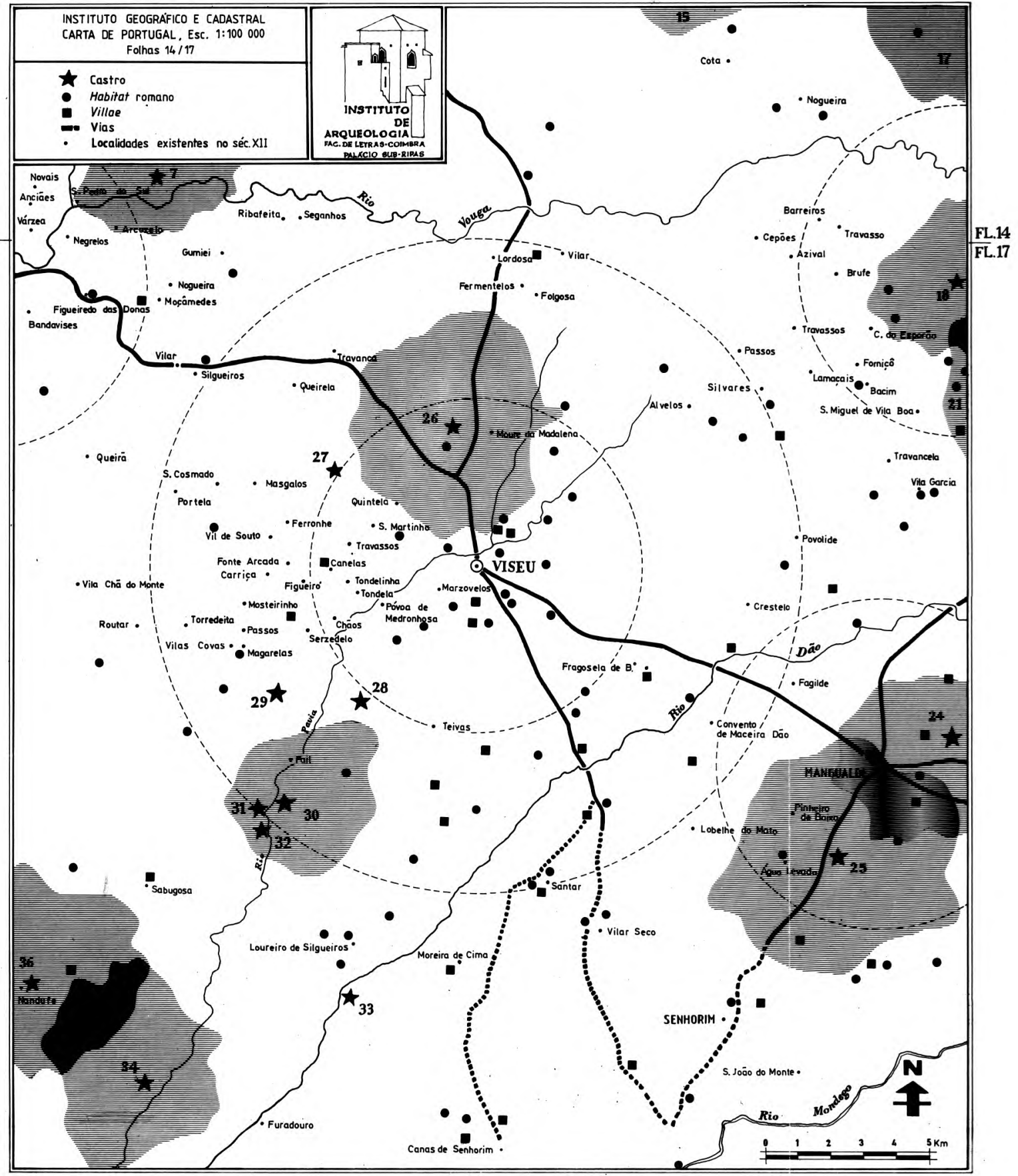


(Página deixada propositadamente em branco) 


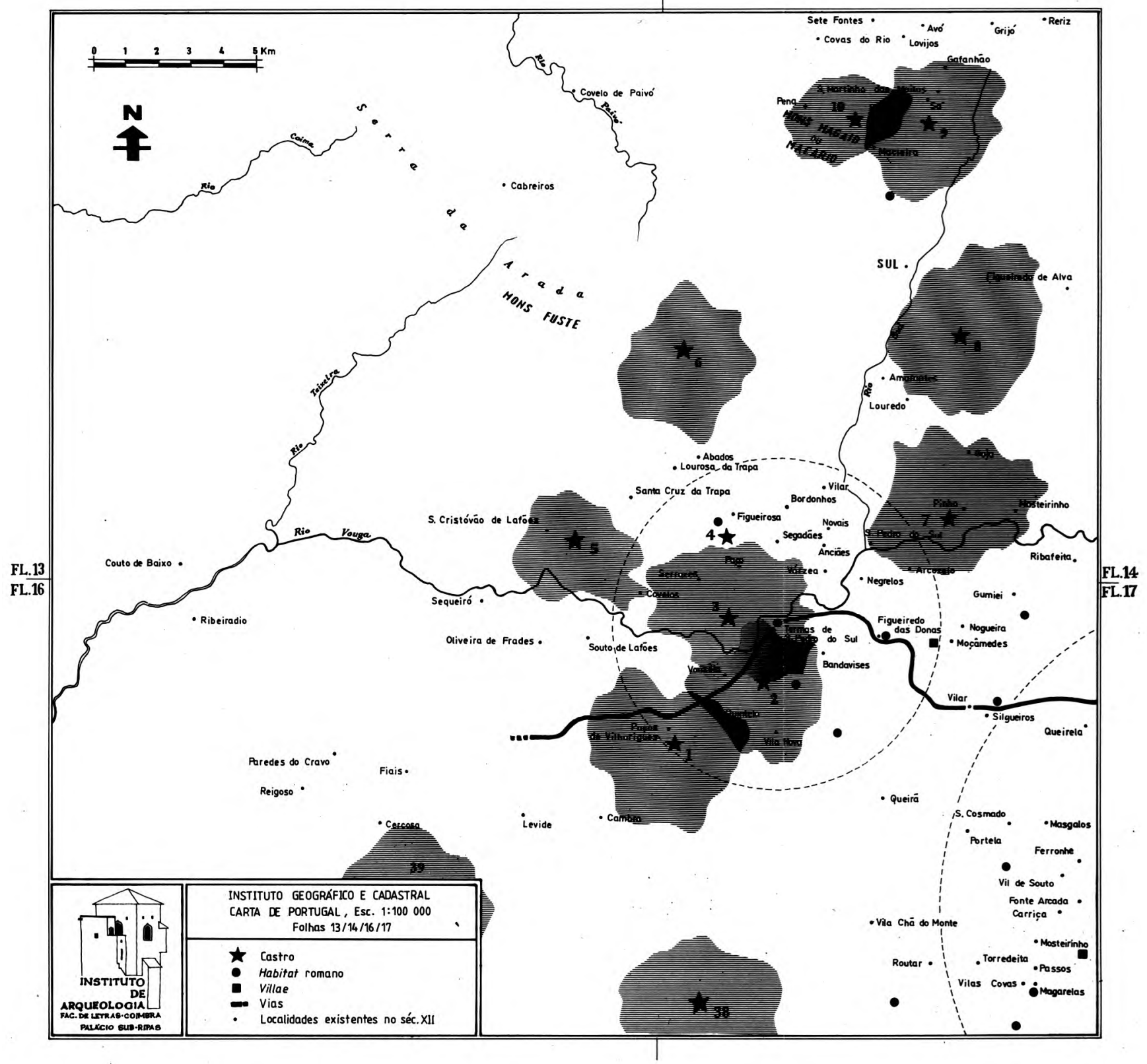


(Página deixada propositadamente em branco) 


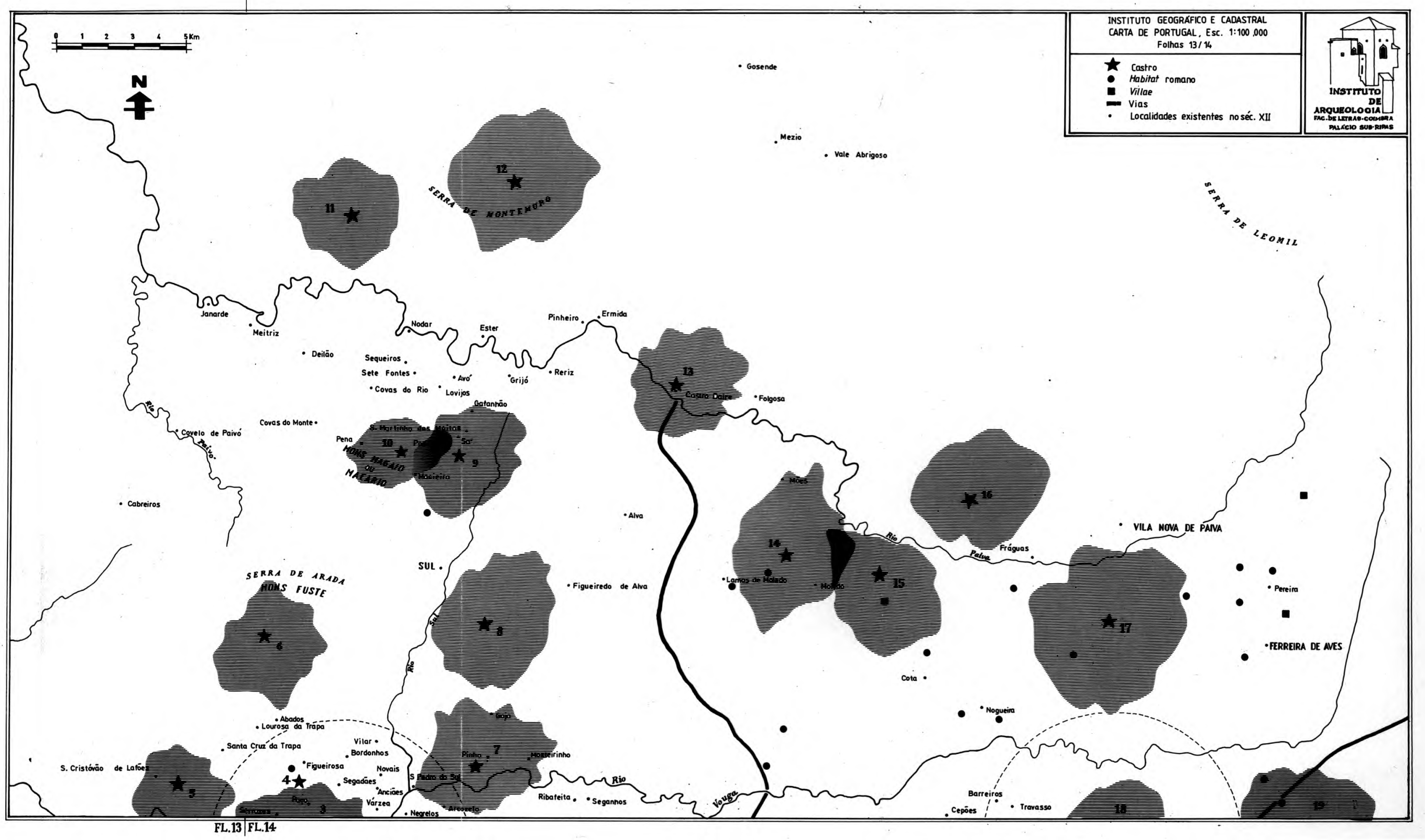





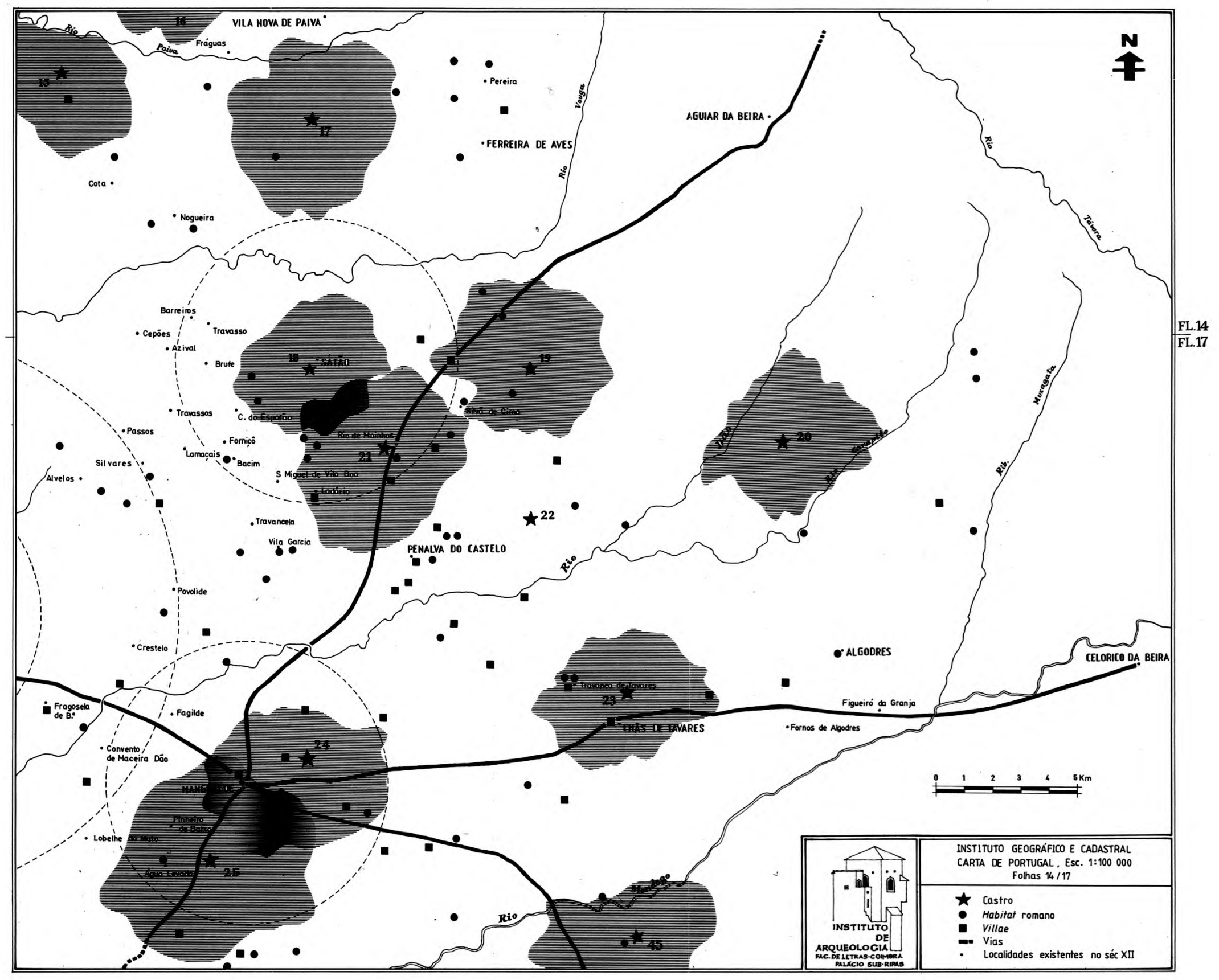


(Página deixada propositadamente em branco) 


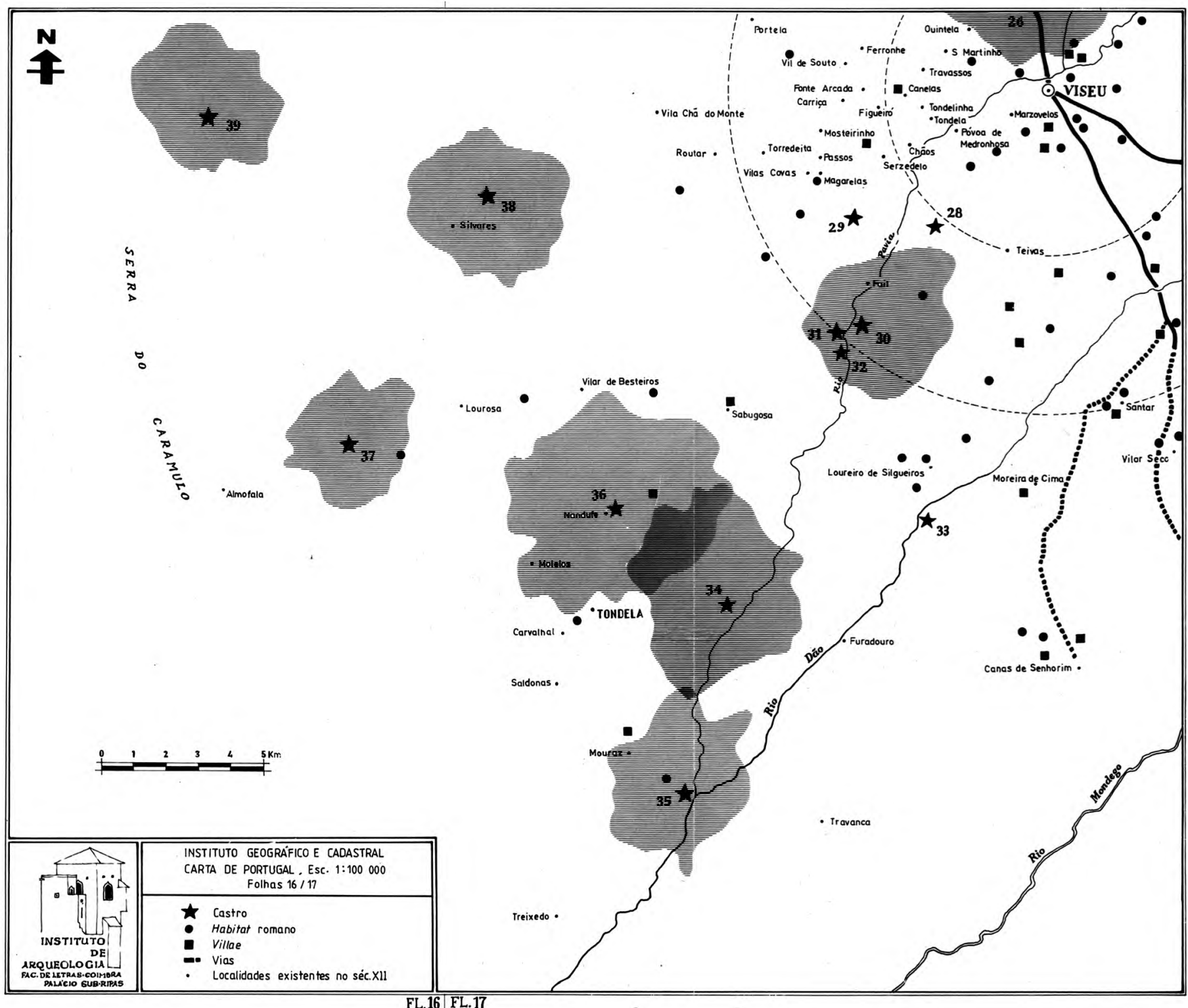





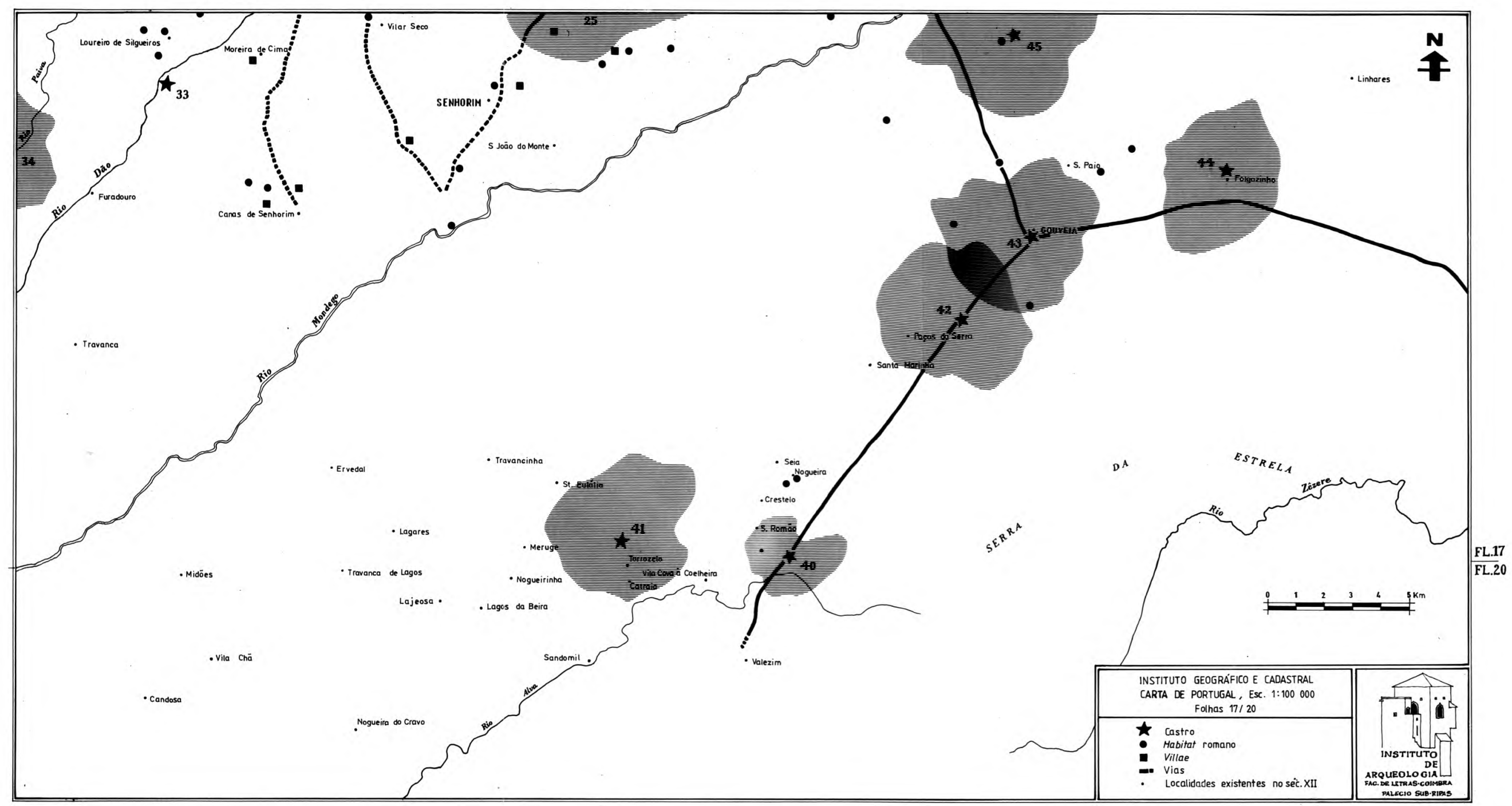

